\title{
MEMBANGUN STRATEGI PEMASARAN UMKM KULINER KAJIAN FENOMENOLOGI ANGKRINGAN DI SURABAYA
}

\author{
ALDO HARDI SANCOKO \\ aldo@ukwms.ac.id \\ VERONIKA RAHMAWATI \\ veronika@ukwms.ac.id
}

DOI : 10.32524/jkb.v17i2.579

\begin{abstract}
The rise of culinary business in angkringan creates its own polemic at food and beverage industry in Surabaya. As the number of angkringan increases, the level of competition among these businesses increases as well. The founder of angkringan also faces hard competition to achieve sustainability in its business. A comprehensive strategy in competing is needed to stay afloat, one of them is a marketing strategy. Hence, qualitative phenomenology research on angkringan in Surabaya is needed to capture the real experience of the founder so as to conclude the appropriate marketing strategy for the angkringan. This research is aimed at SME food and beverage business in angkringan that provides effective marketing strategies for angkringan in Surabaya. This research conclude that the angkringan has few constraints such as minimal working capital, high level of business competition, low level of HR education, and HR hijacking by competitors. Few solutions of this constraints are comprehensive training, supply chain quality improvement, and making SOPs.
\end{abstract}

Keywords: Angkringan, SMEs, Marketing Strategy

\begin{abstract}
ABSTRAKSI
Maraknya bisnis kuliner dalam bentuk angkringan menciptakan polemik tersendiri di dunia usaha makanan dan minuman di Surabaya. Seiring peningkatan jumlah usaha angkringan, meningkat pula tingkat persaingan diantara usaha tersebut. Pendiri usaha angkringan juga menghadapi persaingan ketat untuk dapat tetap bertahan dalam bisnisnya. Strategi secara komprehensif dalam bersaing diperlukan untuk tetap bertahan, salah satu strategi untuk tetap kompetitif adalah strategi pemasaran. Kajian fenomenologi mendalam secara kualitatif pada bisnis angkringan di Surabaya diperlukan untuk menangkap pengalaman riil dari pendiri angkringan sehingga dapat menyimpulkan strategi pemasaran yang tepat guna bagi angkringan tersebut. Penelitian ini ditujukan bagi usaha kuliner UMKM angkringan dimana memberikan luaran berupa strategi pemasaran yang tepat guna bagi angkringan khususnya di Surabaya. Temuan penelitian kualitatif angkringan ini menyimpulkan objek penelitian yang memiliki kendala seperti modal kerja minim, tingkat persaingan usaha tinggi, tingkat edukasi SDM rendah, dan pembajakan SDM oleh kompetitor. Dari kendala tersebut, peneliti memberikan solusi rencana pemasaran melalui pelatihan secara komprehensif, peningkatan kualitas rantai pasok, dan pembuatan SOP yang jelas.
\end{abstract}

Kata Kunci: Angkringan, UMKM, Strategi Pemasaran 


\section{PENDAHULUAN}

Bisnis makanan dan minuman/ kuliner merupakan salah satu jenis usaha yang banyak di yang terus berkembang dan banyak dilirik. Sebab makanan dan minuman merupakan kebutuhan pokok setiap individu yang dibutuhkan setiap hari, tidak heran kalau di kota wisata seperti Surabaya terdapat banyak sekali rumah makan, cafe, warung tenda dan sejenisnya. (www.franchise-expo.co.id).

Ketua Gabungan Pengusaha Makanan dan Minuman Indonesia menjelaskan bahwa bisnis makanan dan minuman selalu masuk lima jenis investasi di Indonesia. Hal itu memicu banyaknya daya tarik investor atas bisnis makanan dan minuman ditambah menjelang Masyarakat Ekonomi ASEAN (MEA) tahun 2015. Pengusaha makanan dan minuman harus menyesuaikan komponen biaya produksi karena kenaikan Upah Minimum Provinsi (UMP) yang mencapai 30\% dan kenaikan BI Rate hingga 7,5\% sehingga tarif dasar listrik dan suku bunga pinjaman naik. Naiknya UMP dan BI Rate menyebabkan investor asing berpeluang masuk ke Indonesia dengan biaya produksi yang lebih rendah. (Industri Makanan Minuman Terus Tumbuh 2014).

Bisnis kuliner yang kian marak ini karena memiliki "lahan" yang cukup potensial dan kreatif dalam pengelolaannya. Berbagai kreasi makanan mulai dari yang unik sampai ekstrem digemari pecinta kuliner Indonesia, termasuk dari segmen makanan tradisional. Tren di bidang kuliner sendiri beragam. Dari sudut pandang pengusaha, tren kuliner terbagi menjadi kubu holistic (makanan sehat) dan kubu makanan mewah/ekstrem/sensasi kuliner yang berbeda. Dari sudut pandang pakar kuliner, pelaku bisnis kuliner tradisional dan cepat saji masih mendominasi. Dari sudut pandang lembaga kuliner seperti Apkrindo (Asosiasi Pengusaha Kafe dan Restoran Indonesia), tren kuliner kedepannya cenderung pada makanan segar yang langsung dimasak di tempat penjual bahan makanan tersebut. (Setyani 2011)

Bisnis kuliner sendiri mudah untuk didirikan karena sederhana dan modal yang dibutuhkan sangat bervariasi serta tidak memerlukan kemampuan teknis yang tinggi untuk menjalankannya. Salah satunya adalah bentuk usaha kuliner "angkringan" yang berasal dari Jawa (khususnya Yogyakarta). Sejarah "angkringan" memang bermula dari upaya menaklukkan kemiskinan usaha ini konon dimulai pada tahun 1950-an oleh mbah pairo karena tidak ada lahan yang subur di desanya di kecamatan Cawas, Klaten. Awalnya para pedagang minuman dan makanan kecil ini tidak menggunakan gerobak melainkan pikulan mereka dulu disebut pedagang hik (dibaca Hek). Nama hik bermula pada tradisi malam selikuran (malam ke-21) di Keraton Surakarta, pada malam tersebut kota berhiaskan lentera (ting-ting) yang antara lain dibawa para pedagang makanan para pedagang itu biasa berteriak Hiik...... iyeeekk..... sampai sekarang istilah hik masih dipakai di Solo. Namun di Yogya mereka populer dengan nama angkringan atau warung kucing (Kompas 2004).

Angkringan berasal dari bahasa Jawa angkring yang berarti alat dan tempat jualan makanan keliling yang pikulannya berbentuk melengkung ke atas) adalah sebuah gerobak dorong untuk menjual berbagai macam makanan dan minuman di pinggir jalan di Jawa Tengah dan Yogyakarta yang dijual dengan harga yang sangat terjangkau. Angkringan juga terkenal sebagai tempat yang egaliter karena bervariasinya pembeli yang datang tanpa membeda-bedakan strata sosial atau SARA. Mereka menikmati makanan sambil bebas mengobrol hingga larut malam meskipun tak saling kenal tentang berbagai hal atau kadang berdiskusi tentang topik-topik yang serius. Harganya yang murah dan tempatnya yang santai membuat angkringan sangat populer di tengah kota sebagai tempat persinggahan untuk mengusir lapar atau sekadar melepas lelah. Akrabnya suasana dalam angkringan membuat nama angkringan tak hanya merujuk kedalam tempat tetapi ke suasana, beberapa acara 
menadopsi kata angkringan untuk menggambarkan suasana yang akrab saling berbagi dan menjembatani perbedaan.

Bentuk usaha angkringan dengan konsep yang sederhana namun populer saat ini dilirik juga oleh bisnis hotel yang notabene berskala besar. Artikel lifestyle di Jawapos yang mencontohkan Hotel Bekizaar di Surabaya yang mengadopsi bentuk usaha angkringan untuk tamu yang hendak memanfaatkan fasilitas F\&B di hotelnya. Terlepas usaha besar, kembali lagi kepada konsep angkringan yang sederhana tadi tentu saja menumbuhkan banyak wirausaha kecil-kecilan yang berkeinginan mendirikan angkringan. Untuk dapat berkompetisi dalam meningkatnya kuantitas bisnis kuliner dengan bentuk angkringan, wirausahawan kecil tersebut perlu strategi pemasaran yang tepat guna karena maraknya model bisnis angkringan dan kurangnya strategi pemasaran bisnis angkringan yang existing di Surabaya saat ini berdasarkan fenomena yang dijabarkan diatas, diperlukan strategi pemasaran optimal bagi angkringan. (Rozack 2017)

Dalam menentukan strategi pemasaran yang tepat bagi usaha angkringan perlu penelitian dengan pendekatan fenomenologi. Fenomenologi melibatkan pengujian kesadaran pengalaman manusia dengan konsep utamanya berupa makna. Makna pentingnya strategi pemasaran muncul dari pengalaman manusia yang perlu diidentifikasi kualitas esensialnya dari pengalaman kesadaran objek penelitian. Dalam penelitian ini, adalah pendiri angkringan atau karyawan yang bekerja di angkringan tersebut secara mendalam dan teliti. (Smith dkk 2009). Fokus penelitian ini guna menggali dan meng-capture fenomena riil di lapangan diantaranya karakteristik pasar angkringan, demand dari pasar atas angkringan, kendala yang dihadapi wirausahawan angkringan, harapan wirausahawan angkringan, dan berbagai hal kualitatif lain secara empirik, tidak hanya normatif saja. Dari fenomena dan problematika wirausaha inilah diperlukan penelitian kualitatif dengan pendekatan fenomenologi terkait strategi pemasaran yang tepat guna (analisis yang digunakan diantaranya adalah (1) PEST terkait politik, ekonomi, sosial, dan teknologi; (2) SWOT - terkait kelebihan, kelemahan, peluang, dan ancaman; dan (3) 4P - terkait produk, harga, lokasi, dan promosi di bagian lampiran) bagi bisnis kuliner bentuk angkringan di Surabaya. Adapun alasan peneliti menggunakan analisis PEST

\section{TELAAH TEORETIS}

Landasan teori yang digunakan adalah Undang-Undang No. 20 Tahun 2008 tentang Usaha Mikro, Kecil, Menengah (UMKM), angkringan, dan strategi pemasaran.

\section{UU No. 20 Tahun 2008}

Usaha Mikro didefinisikan sebagai usaha produktif milik orang perorangan dan/atau badan usaha perorangan yang memenuhi kriteria; sedangkan (2) Usaha Kecil merupakan ekonomi produktif yang berdiri sendiri, yang dilakukan oleh orang perorangan atau badan usaha yang bukan merupakan anak perusahaan atau bukan cabang perusahaan yang dimiliki, dikuasai, atau menjadi bagian baik langsung maupun tidak langsung dari Usaha Menengah atau Usaha Besar yang memenuhi kriteria Usaha Kecil; dan (3) Usaha Menengah adalah usaha ekonomi produktif yang berdiri sendiri, yang dilakukan oleh orang perorangan atau badan usaha yang bukan merupakan anak perusahaan atau cabang perusahaan yang dimiliki, dikuasai, ataupun menjadi bagian baik langsung maupun tidak langsung dengan Usaha Kecil atau Usaha Besar dengan jumlah kekayaan bersih atau hasil penjualan tahunan. Berdasarkan kekayaan dan hasil penjualan, kriteria usaha mikro memiliki kekayaan bersih paling banyak Rp 50.000.000,00 (lima puluh juta rupiah) tidak termasuk tanah dan bangunan tempat usaha dan memiliki hasil penjualan tahunan paling banyak Rp 300.000.000,00 (tiga ratus juta 
rupiah); sementara usaha kecil adalah memiliki kekayaan bersih lebih dari Rp 50.000.000,00 (lima puluh juta rupiah) sampai dengan paling banyak Rp 500.000.000,00 (lima ratus juta rupiah) tidak termasuk tanah dan bangunan tempat usaha dan memiliki hasil penjualan tahunan lebih dari Rp 300.000.000,00 (tiga ratus juta rupiah) sampai dengan paling banyak $\mathrm{Rp}$ 2.500.000.000,00 (dua milyar lima ratus juta rupiah); dan usaha menengah memiliki kekayaan bersih lebih dari Rp 500.000.000,00 (lima ratus juta rupiah) sampai dengan paling banyak Rp 10.000.000.000,00 (sepuluh milyar rupiah) tidak termasuk tanah dan bangunan tempat usaha atau memiliki hasil penjualan tahunan lebih dari Rp 2.500.000.000,00 (dua milyar lima ratus juta rupiah) sampai dengan paling banyak Rp 50.000.000.000,00 (lima puluh milyar rupiah). (Undang-Undang Nomor 20 2008).

\section{Angkringan}

Angkringan berasal dari bahasa pergaulan Jawa, angkring atau nangkring yang artinya duduk santai dan lebih bebas. Para pembeli yang duduk di bangku kayu memanjang di sekitar gerobak angkringan dapat mengangkat atau melipat satu kaki naik ke atas kursi. Angkringan juga merupakan salah satu bentuk variasi dari kaki lima. Penjual kaki lima yang menggunakan pikulan dapat ditemu di daerah lain juga, diantaranya Solo dan Klaten. Masyarakat setempat menyebut kaki lima tersebut dengan nama hik (hidangan istimewa kampung). Istilah ini masih digunakan di Solo, namun istilah yang populer di Yogyakarta adalah angkringan. (Indrawati 2012).

Angkringan juga makanan kaki lima khas di Yogyakarta yang berkembang karena imbas dari krisis ekonomi yang melanda tahun 1997 - 1998. Angkringan masuk dalam usaha informal yang berjenis warung kaki lima, menggunakan gerobak, dan bersifat bergerak (mobile). Pada mulanya, penjual angkringan tidak menggunakan gerobak dorongan beroda dua, melainkan pikulan yang terbuat dari belahan batang bambu yang kedua ujungnya digantungkan dua set perangkat, dilengkapi sebuah bangku untuk penjual. Satu set angkringan dilengkapi alat dan bahan minuman yang akan diolah, termasuk anglo/tungku berbahan bakar arang. Sementara set yang lain memuat bahan makanan siap saji yang hnaya perlu dibakar kembali di atas tungku. Perlengkapan kios berjalan ini masih sederhana karena frekuensi perpindahannya tinggi (mobile). (Hanum 2007).

Konsep angkringan kini adalah gerobak dorong dari kayu dengan tungku arang. Tiga ceret besar di atasnya menjadi alat utama menghidangkan bahan minuman. Suasana remangremang eksotis dari lampu minyak kaca semprong (lampu teplok) menerangi di tengahnya. Tempat duduk/kursi kayu panjang mengelilingi sekitar gerobak yang dinaungi terpal plastik gulung sebagai tenda. Perpaduan inilah yang menjadi nilai estetika angkringan dimana terbentuk melawan waktu dan perkembangan jaman. Hal ini juga yang menjadi daya tarik dari angkringan. (Aini 2013).

\section{Strategi Pemasaran}

Strategi pemasaran merupakan alat fundamental yang direncanakan oleh bentuk usaha dengan mengembangkan keunggulan bersaing yang berkesinambungan melalui pasar yang dimasuki dan program pemasaran yang digunakan untuk melayani sasaran pasar tersebut. (Tjiptono 1997). Strategi pemasaran dapat didefinisikan sebagai rencana dengan pendekatan jangka panjang dan berpandangan ke depan dengan tujuan yang fundamental guna mencapai keunggulan kompetitif yang berkelanjutan. (Baker 2008). Perencanaan strategis ini melibatkan analisis situasi awal strategis perusahaan sebelum melakukan perumusan, evaluasi dan pemilihan posisi kompetitif berorientasi pasar yang berkontribusi terhadap tujuan pemasaran perusahaan. (Homburg dkk. 2009). Strategi pemasaran melibatkan 
pemetaan arah perusahaan untuk periode perencanaan yang akan datang. Hal ini ditinjau $360^{\circ}$ terhadap suatu usaha dan lingkungan operasinya dengan maksud mengidentifikasi peluang bisnis baru yang mungkin dapat dimanfaatkan perusahaan untuk keunggulan kompetitif. Perencanaan strategis juga dapat mengungkapkan ancaman pasar yang mungkin perlu dipertimbangkan perusahaan untuk keberlanjutan jangka panjang. (Frates dkk 2005).

Perencanaan strategis tidak membuat asumsi tentang perusahaan terus menawarkan produk yang sama kepada pelanggan yang sama ke masa depan. Sebaliknya, terkait dengan mengidentifikasi peluang bisnis yang mungkin berhasil dan mengevaluasi kemampuan perusahaan untuk memanfaatkan peluang semacam itu. Ini berusaha untuk mengidentifikasi kesenjangan strategis; Itulah perbedaan antara lokasi perusahaan saat ini (kenyataan strategis atau strategi yang tidak disengaja) dan di mana seharusnya ditempatkan untuk pertumbuhan jangka panjang yang berkelanjutan (strategi niat/ disengaja). (Kerzner 2002).

Seiring meningkatnya kebutuhan akan akuntabilitas, banyak organisasi pemasaran menggunakan berbagai metrik pemasaran untuk melacak kinerja strategis, sehingga tindakan korektif dapat dilakukan sesuai kebutuhan. Di permukaan, perencanaan strategis berusaha menjawab tiga pertanyaan sederhana, namun penelitian dan analisis yang terlibat dalam perencanaan strategis kompleks dan memerlukan banyak skill khusus dan penilaian spesifik lagi. Analisis strategis dirancang untuk menjawab pertanyaan strategis pertama, "Di mana kita sekarang?" Penelitian pasar tradisional kurang bermanfaat untuk pemasaran strategis karena analis tidak mencari wawasan tentang sikap dan preferensi pelanggan. Sebagai gantinya analis strategis mencari wawasan tentang lingkungan operasi perusahaan dengan maksud untuk mengidentifikasi kemungkinan skenario, peluang dan ancaman di masa mendatang. (West dkk 2010).

Perencanaan strategis berfokus pada tiga 3C, yaitu: Pelanggan, Korporasi dan Pesaing. Analisis terperinci dari masing-masing faktor merupakan kunci keberhasilan perumusan strategi. Elemen 'pesaing' mengacu pada analisis kekuatan bisnis yang relatif terhadap saingan dekat, dan pertimbangan ancaman persaingan yang mungkin menimpa kemampuan bisnis untuk bergerak ke arah tertentu. Elemen 'pelanggan' mengacu pada analisis kemungkinan perubahan preferensi pelanggan yang berpotensi menimbulkan peluang bisnis baru. Elemen 'korporasi' mengacu pada analisis terperinci mengenai kemampuan internal perusahaan dan kesiapannya untuk memanfaatkan peluang berbasis pasar atau kerentanannya terhadap ancaman eksternal. (Vliet 2015)

Perencanaan strategis menggunakan berbagai alat penelitian dan teknik analisis, tergantung pada kompleksitas lingkungan dan tujuan perusahaan. Terdapat sekitar 200 teknik analisis kualitatif dan kuantitatif yang secara teratur digunakan oleh analis strategis (Fleitcher dkk 2002). Tidak ada teknik optimal yang dapat diidentifikasi sebagai berguna di semua situasi atau masalah. Menentukan teknik mana yang digunakan dalam situasi tertentu bergantung pada keahlian analis. Pilihan alat tergantung pada berbagai faktor termasuk: ketersediaan data; sifat dari masalah pemasaran; tujuan atau tujuan, tingkat keterampilan analis serta kendala lainnya seperti waktu atau motivasi. (Farris dkk 2015).

Alat dan teknik yang digunakan untuk melakukan analisis strategis adalah: 
Tabel 1

Alat dan Teknik Analisis Strategis

\begin{tabular}{|c|c|}
\hline $\begin{array}{l}\text { Metode dalam meneliti } \\
\text { - Environmental scanning } \\
\text { - Marketing intelligence } \\
\text { - Futures research }\end{array}$ & 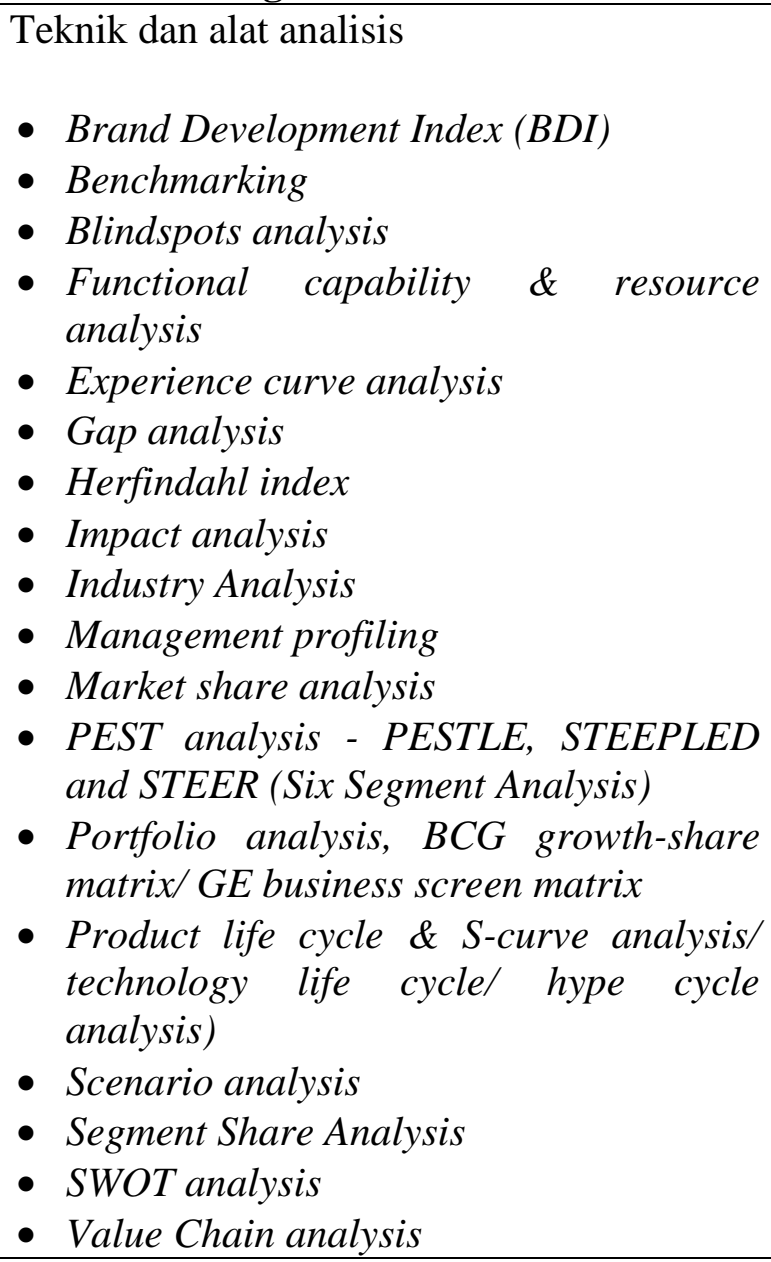 \\
\hline
\end{tabular}

Sumber: Aghazadeh 2016; diolah oleh peneliti

\section{Opsi Strategi Pemasaran yang Digunakan PEST Analysis}

Perencanaan strategis dimulai dengan pemindaian lingkungan bisnis, baik internal maupun eksternal, ini termasuk memahami kendala strategis. (Aaker, 2008). Pemahaman tentang lingkungan operasional eksternal, termasuk politik, ekonomi, sosial dan teknologi yang mencakup aspek demografis dan budaya, diperlukan untuk identifikasi peluang dan ancaman bisnis. Analisis ini disebut PEST yang kepanjangannya: Politik, Ekonomi, Sosial dan Teknologi. Tujuan analisis PEST adalah untuk mengidentifikasi peluang dan ancaman di lingkungan operasi yang lebih luas. Perusahaan mencoba memanfaatkan peluang saat mencoba menahan diri dari ancaman potensial. Pada dasarnya, analisis PEST memandu pengambilan keputusan strategis. (Sammut-Bonnici dkk 2015). Elemen utama analisis PEST adalah:

1. Politik: intervensi politik dengan potensi untuk mengganggu atau meningkatkan kondisi perdagangan (contoh: undang-undang, kebijakan, pendanaan atau subsidi pemerintah, dukungan untuk industri tertentu, perjanjian perdagangan, tarif pajak dan kebijakan fiskal)

2. Ekonomi: faktor ekonomi yang berpotensi mempengaruhi profitabilitas dan harga yang bisa dibebankan (contoh: tren ekonomi, inflasi, nilai tukar, siklus musiman ekonomi, kepercayaan konsumen, daya beli konsumen dan pendapatan diskresioner) 
Aldo Hardi Sancoko dan Veronika Rahmawati

3. Sosial: faktor sosial yang mempengaruhi permintaan akan produk dan layanan, sikap konsumen, selera dan preferensi (contoh: demografi, influencer sosial, role-model, kebiasaan berbelanja.

4. Teknologi: inovasi, perkembangan teknologi atau terobosan yang menciptakan peluang untuk produk baru, proses produksi yang lebih baik, atau cara baru bertransaksi bisnis (contoh: bahan baru, mesin baru, solusi kemasan baru, perangkat lunak baru dan perantara baru)

Peneliti menggunakan analisis PEST karena relevan dengan kondisi angkringan, lokasi penelitian, kemudahan dan kecepatan perolehan data dan menganalisisnya. Selain daripada itu, PEST juga dapat dilakukan untuk memindai lingkungan secara strategis (tidak hanya pemasaran) dimana dapat dijadikan pertimbangan angkringan untuk mengimplementasikan saran dari analisis SWOT), dimana terdapat riset pasar secara eksternal dan gambaran faktor makro yang digunakan dalam mempertimbangkan arah operasi angkringan, mengetahui pertumbuhan/ penurunan pasar, posisi, dan potensi pasar. (Gupta 2013).

\section{Opsi Strategi Pemasaran yang Digunakan Analisis SWOT}

Selain analisis PEST, perusahaan melakukan analisis Strengths, Weakness, Opportunities and Threats (SWOT). (Fine 2010). Analisis SWOT mengidentifikasi:

1. Kekuatan: kemampuan, kompetensi, keterampilan, atau aset khas yang memberikan bisnis suatu keuntungan dari pesaing potensial; faktor internal yang menguntungkan untuk mencapai tujuan perusahaan

2. Kelemahan: kekurangan internal yang menempatkan bisnis pada posisi yang kurang menguntungkan dibandingkan pesaing; atau kekurangan yang mencegah bisnis tersebut bergerak ke arah yang baru atau bertindak berdasarkan peluang; faktor internal yang tidak menguntungkan untuk mencapai tujuan perusahaan

3. Peluang: elemen lingkungan yang bisa dimanfaatkan bisnis atau proyek untuk keuntungannya.

4. Ancaman: unsur lingkungan yang bisa merusak posisi pasar bisnis; faktor eksternal yang mencegah atau menghalangi bisnis tersebut bergerak ke arah yang diinginkan atau mencapai tujuannya.

Biasanya perusahaan akan berusaha memanfaatkan peluang yang bisa disesuaikan dengan kekuatan internal; artinya perusahaan memiliki kemampuan di bidang mana pun dimana kekuatannya disesuaikan dengan peluang eksternal. Mungkin perlu membangun kemampuan jika ingin memanfaatkan peluang di bidang kelemahan. Area kelemahan yang sesuai dengan ancaman eksternal merupakan kerentanan, dan perusahaan perlu mengembangkan rencana kontingensi. (Piercy 2009). Peneliti menggunakan analisis SWOT karena komprehensif dan kompleks dalam menganalisis kelebihan, kekurangan dari sektor internal angkringan sekaligus peluang, ancaman dari sektor eksternal angkringan; hal ini saling terkait dan mempermudah capture kondisi angkringan sekaligus cepat dalam perolehan data dan menganalisisnya, serta dapat dengan mudah diimplementasikan dalam manajemen angkringan sederhana. (Humphrey 2005).

\section{Penelitian Terdahulu}

Penelitian pendukung pertama terkait faktor penghambat dan potensi solusi bagi UMKM di Indonesia yang dimuat dari konferensi internasional bertajuk pengembangan UMKM melalui inovasi dan sustainability. Penelitian ini memetakan fakta bahwa UKM Indonesia memiliki potensi besar terkait dengan kemampuan bertahan di masa krisis dan 
beberapa faktor menjadi alasan mengapa citra UKM Indonesia tidak muncul signifikan meskipun produknya sudah memenuhi keinginan pasar. Penelitian ini menggunakan metode telaah literatur, kuesioner kualitatif dan kuantitatif kepada 200 responden dan in-depth interview kepada setiap responden. Hasilnya, terdapat 10 hambatan utama yang dihadapi UMKM yakni: (1) hambatan kompetisi, (2) akses finansial, (3) harga dari energi, (4) teknologi, (5) biaya produksi yang tidak efisien, (6) faktor ekonomi, (7) kemampuan managerial, (8) proses, (9) batasan penjualan, dan (10) bahan baku. Sebagian UMKM penelitian ini berpendapat pemerintah harus lebih banyak menghapus hambatan bagi mereka, seperti peningkatan standar keamanan, program pembangunan, kebijakan pembiayaan, kebijakan energi yang rasional, evaluasi kinerja berkelanjutan, komitmen penghentian korupsi, dan program pendukung lain yang dibutuhkan oleh UMKM. (Irjayanti dkk 2012)

Penelitian pendukung kedua terkait praktek pemasaran dan dampaknya pada kinerja restoran dan catering kecil menengah di Karachi. menjelaskan bahwa yang paling positif berhubungan dengan performa perusahaan adalah advertising sehingga praktek nonmarketing lainnya adalah waste of money and time. Dari penelitian ini, diambil konklusi bahwa pemasaran menggunakan m-commerce adalah ide yang baik untuk pasar dan pengembangan bisnis; pengadaan tenaga sales juga menstimulus perkembangan bisnis restoran kecil dan menengah di Karachi karena bisa mendapat koneksi ke perusahaan lokal lainnya. Dari sales force juga dapat memperoleh feedback dari konsumen sehingga dapat memperoleh trust antara bisnis dan konsumen. (Ghouri dkk 2011)

Penelitian pendukung ketiga terkait input terhadap bisnis kuliner bernama sumber daya manajemen pengetahuan (knowledge management resource input) yang sangat mempengaruhi efektivitas dalam bisnis restoran. (Kim dkk 2010)

\section{METODE PENELITIAN}

Jenis dan pendekatan penelitian ini adalah kualitatif fenomenologi. Penelitian kualitatif pada hakikatnya ialah mengamati objek secara alamiah dalam lingkungan hidup, berinteraksi, berusaha memahami bahasa dan tafsiran tentang dunia sekitarnya. Penelitian kualitatif ditujukan untuk memahami fenomena apa yang dialami oleh subjek penelitian misalnya perilaku, persepsi, motivasi, tindakan, dan cara deskriptif dalam bentuk kata-kata dan bahasa, pada suatu konteks khusus yang alamiah dan dengan memanfaatkan berbagai metode alamiah (Sugiyono 2014). Peneliti mengamati angkringan secara alamiah, berinteraksi dengan pemilik angkringan, berusaha memahami persepsi pemilik, fenomena yang dialaminya, perilaku terhadap fenomena tersebut, dan dijelaskan secara deskriptif dalam kata-kata.

Penelitian kualitatif menggunakan lima pendekatan, yakni: (1) narrative (Clandinin dkk 2009); (2) grounded theory (Corbin dkk 2007); (3) ethnography (Fetterman 2010, Wolcott 2008); (4) case studies (Yin 2009, 2012); dan (5) phenomenology (Giorgi 2009) yang digunakan peneliti. Tujuan dari pendekatan fenomenologis adalah untuk memberikan gambaran fenomena suatu hal yang spesifik, mengidentifikasi fenomena melalui bagaimana mereka dipersepsikan oleh pelaku dalam sebuah situasi kondisi. Dalam lingkup penelitian yang menggunakan subyek manusia biasanya diterjemahkan ke dalam pengumpulan informasi yang mendalam secara induktif; metode kualitatif seperti wawancara, diskusi, dan observasi partisipan mewakili dari perspektif informan dari penelitian. Fenomenologi berkaitan dengan studi pengalaman dari perspektif individu, diamati, dan diasumsikan berdasarkan informasi fenomena yang ada. Secara epistemologi, pendekatan fenomenologis berbasis paradigma pengetahuan pribadi dan subjektivitas; menekankan pentingnya perspektif pribadi dan interpretasi. Dengan demikian peneliti akan dapat memahami pengalaman subjektif dengan baik, mendapatkan wawasan motivasi dan tindakan subjek 
penelitian, serta dapat mematahkan asumsi konvensional yang selama ini dianut publik. Penelitian kualitatif fenomenologi adalah desain penelitian yang berangkat dari filosofi dan psikologi dimana peneliti menjabarkan pengalaman hidup dari individu-individu tentang fenomena yang diceritakan oleh informan tersebut. Esensi pendekatan fenomenologi adalah peneliti dapat meng-capture pengalaman dari informan yang diperoleh dari observasi dan wawancara.

Peneliti memberi gambaran fenomena secara spesifik dalam suatu situasi kondisi faktual di angkringan. Wawancara mendalam, diskusi dengan pemilik/SDM di dalam angkringan, dan diikuti observasi lingkungan angkringan dilakukan dalam penelitian. Desain dari penelitian angkringan ini akan menjelaskan bagaimana pengalaman pemilik angkringan selaku informan utama dan dapat menarik kendala yang dihadapi serta berkontribusi dalam penyusunan strategi pemasaran yang tepat guna bagi angkringan.

Penelitian kualitatif tidak menggunakan istilah populasi sebagai subyek penelitian, melainkan social situation. Situasi sosial memiliki tiga elemen yakni tempat (place), pelaku (actor), dan aktivitas (activity) yang berinteraksi secara sinergis (Sugiyono 2014), yakni:

1. Tempat: 3 lokasi usaha angkringan di Surabaya yang dipilih secara purposive sesuai kepentingan penelitian. Didokumentasi setelah proses observasi untuk disajikan dalam hasil penelitian.

2. Pelaku: 3 informan yakni pemilik masing-masing usaha angkringan tersebut atau dapat diwakilkan oleh karyawan yang bekerja di angkringan tersebut dan berpengalaman dalam mengelola angkringan yang bersangkutan. Diwawancara dan diproses coding untuk disajikan dalam hasil penelitian.

3. Aktivitas: 4 aktivitas manajemen POAC (planning, organizing, actuating, controlling) (Terry dkk 1994) dan 4 perspektif pengukuran bisnis yakni balanced scorecard (learning \& growth, internal business process, customer, financial) (Kaplan dkk 1995).

Peneliti memilih tiga subyek penelitian ini karena memiliki kesamaan bentuk usaha yakni angkringan dan untuk kebutuhan keabsahan data (triangulasi sumber) karena pada penelitian kualitatif tidak menggunakan rumus atau teknik uji keabsahan data yang bersifat kuantitatif melainkan coding ucapan informan, triangulasi, dan member check (peneliti kembali ke informan untuk mengklarifikasi ulang hasil olahan data penelitian sebelumnya).

Dari segi teknik pengumpulannya, pengumpulan data didapat dengan observasi atau pengamatan, interview atau wawancara, kuesioner atau angket, dokumentasi, dan gabungan keempatnya atau triangulasi. Penelitian ini menggunakan prosedur pengumpulan data primer melalui wawancara mendalam (in-depth interview) dengan model semi terstruktur, sedangkan pengumpulan data sekunder melalui dokumentasi fisik informan dari lokasi angkringan di Surabaya. Wawancara yang digunakan dalam penelitian ini adalah semi-terstruktur atau semistructured interview. Wawancara semi-terstruktur masuk dalam kategori in-depth interview yang pelaksanaannya lebih bebas dibandingkan wawancara terstruktur. Tujuan wawancara semi-terstruktur adalah untuk menemukan permasalahan dengan lebih terbuka di mana pihak yang diajak wawancara diminta pendapat atau feedback serta ide-idenya.

Sedangkan pengumpulan data sekunder menggunakan dokumentasi. Dokumen merupakan catatan peristiwa yang sudah berlalu; berbentuk tulisan, gambar, dan karya seseorang. Dalam penelitian kualitatif, hasil penelitian akan lebih kredibel kalau didukung dengan sejarah pribadi kehidupan di sekolah, tempat kerja, masyarakat, dan autobiografi; ditambah dengan foto atau karya akademik dan seni yang ada. Dalam penelitian ini, beberapa informasi mengenai sejarah angkringan yang diteliti akan didokumentasikan serta disajikan sebagai hasil penelitian. 
Analisis data adalah proses mencari dan menyusun sistematika data yang diperoleh dari hasil wawancara, catatan lapangan, dan dokumentasi, dengan cara mengorganisasikan data ke dalam kategori, menjabarkan ke dalam unit, melakukan sitesa, menyusun ke dalam pola, memilih mana yang penting dan dipelajari, dan membuat kesimpulan sehingga dapat dipahami. Dalam penelitian kualitatif ini, hasil observasi, wawancara, dan dokumentasi dikategorikan sesuai dengan keperluan menjawab rumusan masalah, bagaimana dan sejauh apa peran strategi pemasaran secara kualitatif sehingga dipahami oleh pihak yang berkepentingan. Keabsahan data akan ditekankan dalam uji validitas, di mana kriteria utama data hasil penelitian adalah valid, reliable, dan objektif (Sugiyono 2014).

Validitas merupakan derajat ketepatan antara data yang terjadi pada objek penelitian dengan daya yang dapat dilaporkan oleh peneliti. Validitas dibagi menjadi dua yaitu internal yang berkaitan dengan akurasi desain penelitian dengan hasil yang dicapat dan eksternal yang berkaitan dengan akurasi hasil penelitian dapat digeneralisasi atau diimplementasikan pada social situation. Upaya pengujian validitas dibagi menjadi enam, yaitu perpanjangan pengamatan, peningkatan ketekunan, triangulasi, diskusi, analisis kasus negatif, dan member check. Penelitian ini menggunakan uji validitas triangulasi dan membercheck.

Triangulasi merupakan pengecekan data dari berbagai sumber dengan berbagai cara, dan berbagai waktu. Triangulasi yang digunakan dalam penelitian ini adalah triangulasi sumber. Triangulasi sumber mencek data yang diperoleh melalui berbagai sumber. Di mana dari informan alternatif pertama yaitu pihak pemilik angkringan 1 akan ditriangulasi dengan informan alternatif kedua dan ketiga yaitu pihak pemilik angkringan 2 dan 3 untuk memvalidasi pernyataan tentang fenomena angkringan, strategi pemasaran dan kondisi faktual yang dihadapinya. Lalu dari informan akan dikategorisasikan, dipilih pandangan yang sama, yang berbeda, dan spesifik informan tersebut.

Membercheck merupakan proses pengecekan data yang diperoleh peneliti kepada pemberi data. Tujuannya adalah mengetahui seberapa jauh data yang diperoleh sesuai dengan apa yang diberikan oleh informan. Dalam penelitian ini, setelah pengumpulan data selesai, atau setelah menemukan kesimpulan, peneliti akan secara individu datang ke informan untuk menyampaikan kesimpulan atas data yang dianalisis. Setelah disepakati, maka informan diminta menandatangani hasil tersebut agar lebih otentik dan menjadi bukti peneliti melakukan member-check. Proses member-check yang dilakukan peneliti disertai pembubuhan tanda tangan informan untuk kesediaannya dipublikasi hasil wawancara demi kepentingan riset dan pendidikan.

Aktivitas dalam analisis data kualitatif dilakukan secara interaktif dan kontinu sampai tuntas. Aktivitas atau proses dalam analisis data mengalami tiga langkah analisis, yakni:

(1) Reduksi data atau data reduction. Di mana proses seleksi data terjadi, dihimpun dari lapangan sesuai kebutuhan atau kategori yang ditentukan. Bertujuan untuk memperoleh informasi yang lebih fokus dan memang diperlukan. Data hasil wawancara dan observasi akan direduksi sampai titik hanya menjawab rumusan masalah penelitian saja; (2) Penyajian data atau data display. Di mana setelah direduksi, data disajikan dalam bentuk uraian singkat, bagan, hubungan antar kategori, dan flowchart. Dalam penelitian ini, data disajikan dalam bentuk teks naratif; (3) Verifikasi atau conclusion drawing. Di mana terjadi penarikan kesimpulan atas bukti valid dari proses memperoleh data. Jika mendukung valid, reliable, dan objektif, maka dijadikan kesimpulan akhir. Konklusi akan didasarkan pada kedalaman pembahasan strategi pemasaran yang tepat guna bagi angkringan di Surabaya sekaligus jawaban atas rumusan masalah penelitian. Dalam proses analisis data penelitian ini, tidak digunakan tools spesifik untuk grouping informasi. Alih-alih mengambil data dengan teknik pengambilan data yang dijelaskan pada poin sebelumnya hingga data yang diperoleh jenuh 
Aldo Hardi Sancoko dan Veronika Rahmawati

dan memenuhi kebutuhan penelitian. Mengelompokkan informasi akan secara otomatis dilakukan saat mereduksi data (melalui screening manual dari ucapan informan) sehingga tools grouping informasi tidak digunakan.

\section{HASIL DAN PEMBAHASAN}

Penelitian kualitatif dengan pendekatan fenomenologi digunakan dalam penelitian ini untuk mengungkapkan makna dari sudut pandang produsen (pemilik atau manajer) angkringan. Pemaparan hasil penelitian dibagi menjadi tiga yakni: (1) bagian pertama yang memperkenalkan tiga informan yang menjadi narasumber penelitian ini, perkenalan informan juga memberikan penjelasan perihal pemilihan informan, demografi, dan gambaran pengalaman dari tiap informan dalam menjalankan angkringan yang didirikannya/dikelolanya; (2) bagian kedua yang menyajikan penjelasan perihal analisis data yang digunakan dalam penelitian ini; dan (3) bagian ketiga yang menyajikan temuan penelitian mengenai konstruk rencana pemasaran bagi angkringan sebagai output penelitian.

Tabel 2

\section{Data Demografi Informan}

\begin{tabular}{lllll}
\hline No & Nama & Jabatan & Usia & Pekerjaan \\
\hline 1 & Afifah & Pemilik & 23 tahun & Karyawan Swasta \\
\hline 2 & Marga & Pemilik & 40 tahun & Karyawan Swasta \\
\hline 3 & Sugeng & Pemilik & 33 tahun & Wirausahawan \\
\hline
\end{tabular}

Dasar penelitian ini adalah ketertarikan peneliti untuk menemukan rencana pemasaran yang membuat angkringan di Surabaya lebih kompetitif dalam bersaing dengan usaha makanan minuman modern. Mengingat saat ini banyak resto atau usaha makanan/minuman yang unik, bermodal besar, dan lebih kompetitif, bisnis angkringan secara subyektif oleh peneliti dipandang kurang mumpuni jika menggunakan strategi pemasaran yang mainstream. Melihat persepsi pemilik/manajer tentang pemasaran memerlukan narasumber yang mampu menceritakan opininya secara lugas dan detail mengenai pengalaman mengelola angkringan, maka itu peneliti melakukan in-depth interview. Untuk menentukan angkringan dan informan yang dijadikan objek penelitian, peneliti menggunakan purposive sampling dimana angkringan yang ditentukan adalah angkringan yang menjual minuman tradisional jogja dan berbagai jenis makanan khas Jogja, bukan angkringan abal-abal yang berkonsep modern (memiliki wifi, menjual makanan berat, dll), sedangkan untuk narasumber/informannya adalah pemilik yang mengetahui operasional angkringan tersebut. Peneliti memilih individuindividu tersebut karena mereka dapat secara spesifik memberi pemahaman perihal pemasaran angkringan yang ditinjau di penelitian ini. Ukuran sampel penelitian kualitatif bukan hanya sekedar mempelajari lokasi ataupun individu, melainkan untuk mengumpulkan rincian yang luas tentang masing-masing lokasi atau individu yang dipelajari. Tujuannya bukan untuk atau menggeneralisasi informasi tetapi untuk menguraikan yang tertentu dan yang spesifik (Creswell 2009).

Sebelum menemukan informan, peneliti melakukan pengamatan/observasi. Pengamatan disini penting untuk mengumpulkan data dalam penelitian kualitatif. Melakukan observasi berarti memperhatikan fenomena di lapangan melalui panca indra peneliti, langsung turun ke lapangan untuk mengamati perilaku dan aktivitas individu di angkringan. Setelah melalui langkah proses observasi tersebut, peneliti akan menemukan informasi yang kemudian dilanjutkan dengan proses wawancara. Wawancara yang dilakukan peneliti adalah in-depth 
interview yang 1-on-1 (satu-lawan-satu) dengan jenis wawancara semi terstruktur karena mengajukan pertanyaan dari panduan wawancara.

Temuan Penelitian

Subjek Penelitian (Situasi Sosial)

Tabel 3

Temuan Situasi Sosial

\begin{tabular}{ccll}
\hline No & Situasi Sosial & \multicolumn{1}{c}{ Objek Penelitian } & \multicolumn{2}{c}{ Temuan } \\
\hline 1 & Tempat & Angkringan Teman Lama & Ngagel, Surabaya \\
& & Angkringan Ngudi Raos & Kaliwaron, Surabaya \\
& & Angkringan Ngudi Roso & Rungkut, Surabaya \\
\hline 2 & Pelaku & Angkringan Teman Lama & Afifah (23 tahun) \\
& & Angkringan Ngudi Raos & Marga (40 tahun) \\
& Angkringan Ngudi Roso & Sugeng (33 tahun) & \\
\hline 3 & Aktivitas & Ketiga Objek penelitian & Kegiatan pengolahan dan penjualan \\
& & makanan/minuman tradisional Jogja \\
& & & dalam bentuk usaha angkringan \\
\hline
\end{tabular}

\section{PEMBAHASAN}

Dari hasil temuan penelitian ketiga objek, sesuai dengan perumusan masalah dan tujuan penelitian, disusunlah strategi pemasaran dari alat analisis pemasaran PEST dan SWOT dari tiap objek penelitian. Analisis dimulai dengan Matriks Evaluasi Faktor Internal (Internal Factor Evaluation/ IFE) dan Matriks Evaluasi Faktor Eksternal (External Factor Evaluation/ EFE) yang merupakan alat manajemen strategis untuk mengaudit atau mengevaluasi kekuatan dan kelemahan utama dalam bidang fungsional bisnis. Matriks IFE memberikan dasar untuk mengidentifikasi dan mengevaluasi hubungan antara bidang-bidang tersebut, yang bersamaan dengan matriks EFE menjadi alat perumusan strategi yang dapat digunakan untuk mengevaluasi kinerja UMKM dalam hal mengidentifikasi kekuatan dan kelemahan internal perusahaan. Dari matriks IFE dan EFE, dipilih variabel kontributor dengan skor terbesar yang akan dimasukkan dalam analisis SWOT/ kekuatan kelemahan peluang dan ancaman (Strengths-Weaknesses-Opportunities-Threats). Selain menganalisis SWOT, luaran dari penelitian ini berupa analisis sektor politik, ekonomi, sosial, dan teknologi (PEST).

\section{Matriks IFE \& EFE}

Matriks IFE dan EFE dibuat menggunakan lima langkah:

1. Peneliti mengawalinya dengan mencari faktor internal utama dengan audit internal berikut mengidentifikasi kekuatan dan kelemahan di ketiga objek angkringan dan diperoleh 8 faktor internal dari ketiga objek angkringan. Jumlah faktor tidak berpengaruh pada kisaran skor average total karena bobot total selalu berjumlah 1,00 tetapi kuantitas faktor membantu mengurangi kesalahan estimasi yang dihasilkan dari penilaian subjektif peneliti. Peneliti membuat daftar kekuatan dan kelemahan dengan sespesifik dan seobjektif mungkin.

2. Langkah kedua setelah mengidentifikasi kekuatan dan kelemahan, inti dari matriks IFE dan EFE adalah memberikan bobot yang berkisar dari 0,00 hingga 1,00 untuk setiap faktor. Bobot yang diberikan pada faktor menunjukkan kepentingan relatif faktor tersebut. Nol berarti tidak penting. Satu menunjukkan sangat penting. Faktor dengan kepentingan terbesar dalam kinerja angkringan diberi bobot tertinggi. Setelah menetapkan bobot untuk masing-masing faktor, peneliti memastikan jumlah semua bobot sama dengan 1,00. 
Aldo Hardi Sancoko dan Veronika Rahmawati

3. Setelah itu, peneliti menetapkan peringkat 1 hingga 4 untuk setiap faktor. Peringkat ini menjawab apakah faktor tersebut mewakili kelemahan utama (peringkat $=1$ ), kelemahan kecil (peringkat $=2$ ), kekuatan kecil (peringkat $=3$ ), atau kekuatan utama (peringkat $=4$ ). Kekuatan menerima peringkat 4 atau 3 dan kelemahan menerima peringkat 1 atau 2.

4. Langkah keempat adalah melipatgandakan bobot masing-masing faktor berdasarkan peringkatnya dan memberi skor rerata untuk setiap faktor.

5. Dan diakhiri dengan menjumlahkan skor rerata untuk setiap faktor. Ini memberikan skor total rerata dalam IFE/EFE.

Tabel 4

IFE Matrix Angkringan Teman Lama

\begin{tabular}{lccc}
\hline \multicolumn{1}{c}{ Kekuatan Internal } & Bobot & Peringkat & Skor Rerata \\
\hline Adaptif terhadap permintaan pasar & 0.35 & 3 & 1.05 \\
\hline Koordinasi cepat karena birokrasi sederhana & 0.15 & 2 & 0.3 \\
\hline Pemilik menggunakan modal sendiri & 0.1 & 2 & 0.2 \\
\hline Makanan bervariasi & 0.1 & 1 & 0.1 \\
\hline Kelemahan Internal & & & \\
\hline Mental dari pemilik yang lemah & 0.15 & 3 & 0.45 \\
\hline Jam operasional tidak menentu & 0.05 & 3 & 0.15 \\
\hline Bergantung pada ketersediaan karyawan & 0.06 & 2 & 0.12 \\
\hline Rasa standar & 0.04 & 1 & 0.04 \\
\hline Total Skor Rerata & 1 & & $\mathbf{2 . 4 1}$ \\
\hline
\end{tabular}

Tabel 5

EFE Matrix Angkringan Teman Lama

\begin{tabular}{lccc}
\hline \multicolumn{1}{c}{ Peluang } & Bobot & Peringkat & Skor Rerata \\
\hline Perubahan gaya hidup remaja & 0.20 & 3 & 0.60 \\
\hline Tren makanan minuman yangfast moving & 0.15 & 3 & 0.45 \\
\hline $\begin{array}{l}\text { Banyak penyelia makanan/minuman yang hanya } \\
\text { sebagai substitutor (kompetitor substitusi) }\end{array}$ & 0.15 & 3 & 0.45 \\
\hline Pemerintah mempermudah regulasi UMKM & 0.20 & 1 & 0.20 \\
\hline Ancaman & & & \\
\hline Banyak pesaing langsung dan tidak langsung & 0.15 & 3 & 0.45 \\
\hline $\begin{array}{l}\text { Banyak pesaing yang melakukan benchmark ke } \\
\text { angkringan lain }\end{array}$ & 0.1 & 3 & 0.3 \\
\hline $\begin{array}{l}\text { UMKM kesulitan untuk kompetitif karena banyak } \\
\text { pemain besar }\end{array}$ & 0.025 & 2 & 0.05 \\
\hline Konsumen mudah bosan & 0.025 & 2 & 0.05 \\
\hline Total Skor Rerata & 1 & & $\mathbf{2 . 5 5}$ \\
\hline
\end{tabular}

Total skor rerata IFE untuk Angkringan Teman Lama relatif rendah (di bawah angka 2.5) yang berarti bisnisnya cukup lemah secara pengelolaan internal; sementara EFE sedikit lebih baik (di atas angka 2.5) yang artinya bisnisnya sedikit lebih baik dalam kemampuannya merespon faktor eksternal seperti peluang baru dan ancaman dari pihak luar. (David 1997). 
Langkah berikutnya adalah peneliti menganalisis SWOT berdasarkan kekuatan kelemahan peluang dan ancaman dengan bobot terbesar dan mencari strategi/solusinya.

Tabel 6.

IFE Matrix Angkringan Ngudi Raos

\begin{tabular}{lccc}
\hline \multicolumn{1}{c}{ Kekuatan Internal } & Bobot & Peringkat & Skor Rerata \\
\hline Memiliki dapur sendiri & 0.3 & 4 & 1.2 \\
\hline Rasa yang konsisten & 0.15 & 3 & 0.45 \\
\hline SDM yang sesuai dengan konsep angkringan & 0.15 & 3 & 0.45 \\
\hline Makanan bervariasi & 0.1 & 1 & 0.1 \\
\hline Kelemahan Internal & & & \\
\hline Masing menggunakan sistem kepercayaan & 0.15 & 3 & 0.45 \\
\hline Pendidikan SDM rendah & 0.05 & 3 & 0.15 \\
\hline Mudah dibajak oleh kompetitor & 0.05 & 3 & 0.15 \\
\hline Rasa standar & 0.05 & 1 & 0.05 \\
\hline Total Skor Rerata & 1 & & $\mathbf{3 . 0 0}$ \\
\hline
\end{tabular}

Tabel 7

EFE Matrix Angkringan Ngudi Raos

\begin{tabular}{lccc}
\hline Peluang & Bobot & Peringkat & Skor Rerata \\
\hline Modal UMKM angkringan rendah & 0.25 & 3 & 0.75 \\
\hline $\begin{array}{l}\text { Konsep tradisional Jogja berbeda dengan resto } \\
\text { modern }\end{array}$ & 0.15 & 3 & 0.45 \\
\hline Memiliki segmen tersendiri (niche market) & 0.15 & 3 & 0.45 \\
\hline Pemerintah mempermudah regulasi UMKM & 0.10 & 1 & 0.10 \\
\hline Ancaman & & & \\
\hline Pembajakan SDM dari kompetitor sejenis & 0.15 & 3 & 0.45 \\
\hline Banyak kompetitor di sektor makanan minuman & 0.10 & 3 & 0.3 \\
\hline UMKM sulit kompetitif karena banyak pemain besar & 0.05 & 2 & 0.1 \\
\hline Konsumen mudah bosan & 0.05 & 1 & 0.05 \\
\hline Total Skor Rerata & 1 & & $\mathbf{2 . 6 5}$ \\
\hline
\end{tabular}

Total skor rerata IFE untuk Angkringan Ngudi Raos tinggi (di atas angka 2.5) yang berarti bisnisnya mumpuni dan kredibel pengelolaan internalnya; sementara EFE sedikit lebih baik (di atas angka 2.5) yang artinya bisnisnya sedikit lebih baik dalam kemampuannya merespon faktor eksternal seperti peluang baru dan ancaman dari pihak luar. (David 1997). Langkah berikutnya adalah peneliti menganalisis SWOT berdasarkan kekuatan kelemahan peluang dan ancaman dengan bobot terbesar dan mencari strategi/ solusinya. 
Tabel 8

IFE Matrix Angkringan Ngudi Roso

\begin{tabular}{llll}
\hline Kekuatan Internal & Bobot & Peringkat & Skor Rerata \\
\hline Prioritas pada layanan pelanggan & 0.15 & 3 & 0.45 \\
\hline Promo tiap hari berganti & 0.15 & 2 & 0.3 \\
\hline Pemilik komunikatif dengan pelanggan & 0.15 & 2 & 0.3 \\
\hline Makanan bervariasi & 0.05 & 1 & 0.05 \\
\hline Kelemahan Internal & & & \\
\hline Lokasi tidak nyaman dan strategis & 0.25 & 3 & 0.75 \\
\hline $\begin{array}{l}\text { Ketersediaan produk rendah karena tidak ada proyeksi } \\
\text { penjualan }\end{array}$ & 0.15 & 2 & 0.3 \\
\hline Karyawan sedikit & 0.05 & 1 & 0.05 \\
\hline Rasa standar & 0.05 & 1 & 0.05 \\
\hline Total Skor Rerata & 1 & & $\mathbf{2 . 2 5}$ \\
\hline
\end{tabular}

Tabel 9

EFE Matrix Angkringan Ngudi Roso

\begin{tabular}{lccc}
\hline Peluang & Bobot & Peringkat & Skor Rerata \\
\hline $\begin{array}{l}\text { Preferensi pilihan makanan konsumen cenderung } \\
\text { makanan berat }\end{array}$ & 0.2 & 2 & 0.4 \\
\hline $\begin{array}{l}\text { Perubahan perilaku konsumen yang menuntut } \\
\text { fasilitas modern seperti wifi }\end{array}$ & 0.2 & 3 & 0.6 \\
\hline $\begin{array}{l}\text { Industri makanan minuman bermodal rendah } \\
\text { Pemerintah mempermudah regulasi UMKM }\end{array}$ & 0.1 & 2 & 0.1 \\
\hline Ancaman & & 1 & 0.1 \\
\hline $\begin{array}{l}\text { Angkringan dengan konsep menyimpang jauh dari } \\
\text { aslinya merusak persepsi publik tentang angkringan } \\
\text { karena menjual menu yang berbeda jauh. }\end{array}$ & & 3 & 0.2 \\
\hline $\begin{array}{l}\text { Resto dengan konsep modern dapat menjadi } \\
\text { alternatif angkringan karena fasilitasnya lebih baik }\end{array}$ & 0.1 & 2 & 0.2 \\
\hline Banyak pesaing langsung dan tidak langsung & 0.05 & 2 & 0.1 \\
\hline $\begin{array}{l}\text { Konsumen mudah bosan } \\
\text { Total Skor Rerata }\end{array}$ & 1 & 2 & 0.1 \\
\hline
\end{tabular}

Total skor rerata IFE untuk Angkringan Ngudi Roso rendah (di bawah angka 2.5) yang berarti bisnisnya lebih lemah secara pengelolaan internal dibandingkan objek pertama dan kedua; diikuti EFE yang juga rendah (di bawah angka 2.5) yang artinya bisnisnya sedikit kurang mampu dalam merespon faktor eksternal seperti peluang baru dan ancaman dari pihak luar. (David 1997). Langkah berikutnya adalah menganalisis SWOT berdasarkan kekuatan kelemahan peluang dan ancaman dengan bobot terbesar dan mencari strategi/ solusinya.

\section{Analisis SWOT}

Variabel pada analisis SWOT berikut didasarkan pada kekuatan kelemahan peluang dan ancaman yang diperoleh dari matriks IFE dan EFE sebelumnya dengan bobot skor tertinggi. Kode huruf dan angka di belakang variabel merupakan coding dari transkrip hasil 
wawancara dengan objek penelitian (di bagian lampiran). Analisis SWOT ini juga dapat menjadi strategi bisnis besar bagi Angkringan yang kelak dapat diimplementasikan tidak hanya dalam kegiatan pemasaran melainkan juga pada kegiatan strategis operasional dan pengelolaan SDM.

\section{Analisis SWOT Angkringan Teman Lama}

Analisis SWOT Angkringan Teman Lama dilakukan dalam tiga tahapan (Piercy 2009) berikut:

1. Menganalisis lingkungan internal dan eksternal dari Objek (tahapan satu dan dua).

Dalam penelitian ini, analisis lingkungan internal maupun eksternal dilakukan melalui open questions dalam wawancara. Temuan dari hasil wawancara melalui responden/ informan pertama yakni Afifah dituangkan dalam tabel berikut:

Tabel 10

Temuan SWOT Angkringan Teman Lama

\begin{tabular}{|c|c|c|}
\hline $\begin{array}{l}\text { Matriks } \\
\text { SWOT } \\
\text { Angkring } \\
\text { an } \\
\text { Teman } \\
\text { Lama }\end{array}$ & Helpful/ Membantu & Harmful/ Berbahaya \\
\hline 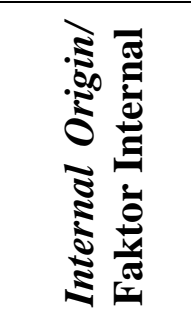 & 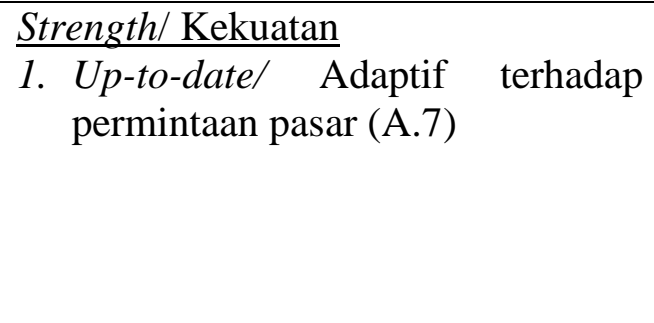 & $\begin{array}{l}\frac{\text { Weaknesses/ Kelemahan }}{\text { 1. Lemahnya mental dari pemilik }} \\
\text { (A.8) } \\
\text { 2. Jam buka tidak menentu karena } \\
\text { tergantung oleh kesediaan } \\
\text { karyawan (A.9) }\end{array}$ \\
\hline 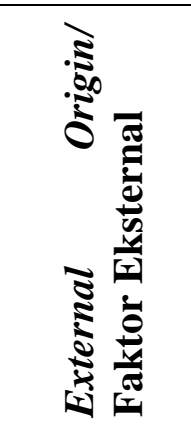 & $\begin{array}{l}\text { Opportunities/ Peluang } \\
\text { 1. Perubahan gaya hidup remaja } \\
\text { (A.10) } \\
\text { 2. Tren makanan minuman yang fast } \\
\text { moving (A.13) } \\
\text { 3. Adanya pesaing tidak langsung } \\
\text { penyelia makanan/minuman } \\
\text { substitusi (A.20) }\end{array}$ & $\begin{array}{l}\text { Threats/ Ancaman } \\
\text { 1. Banyak pesaing langsung } \\
\text { maupun tidak langsung (A.15, } \\
\text { A.19) } \\
\text { 2. Pesaing benchmark ke } \\
\text { angkringan (A.16-A.17) }\end{array}$ \\
\hline
\end{tabular}

2. Melakukan analisis SWOT dan dokumen dari Objek (tahapan tiga).

Dalam penelitian ini, analisis SWOT berupa strategi-strategi yang dapat diimplementasikan oleh Angkringan Teman Lama adalah sebagai berikut: 
Tabel 11

Strategi SWOT Angkringan Teman Lama

\begin{tabular}{|c|c|c|}
\hline $\begin{array}{l}\text { Strategi SO } \\
\text { Strategi WO } \\
\text { Strategi ST } \\
\text { Strategi WT } \\
\text { Angkringan Teman } \\
\text { Lama }\end{array}$ & $\begin{array}{l}\text { Strengths } \\
\text { 1. Up-to-date/ } \\
\text { Adaptif terhadap } \\
\text { permintaan pasar } \\
\text { (A.7) }\end{array}$ & $\begin{array}{l}\text { Weaknesses } \\
\text { 1. Lemahnya mental dari pemilik } \\
\text { (A.8) } \\
\text { 2. Jam buka tidak menentu karena } \\
\text { tergantung oleh kesediaan } \\
\text { karyawan (A.9) }\end{array}$ \\
\hline 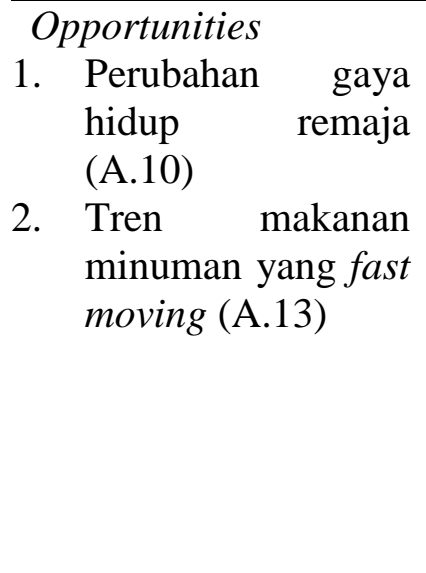 & $\begin{array}{l}\text { Strategi SO } \\
\text { 1. Memanfaatkan } \\
\text { fleksibilitas } \\
\text { dalam } \\
\text { peningkatan } \\
\text { inovasi dan } \\
\text { adaptif terhadap } \\
\text { perkembangan } \\
\text { jaman (S1, O1, } \\
\text { O2) }\end{array}$ & $\begin{array}{l}\text { Strategi WO } \\
\text { 1. Mengikuti pelatihan/ seminar } \\
\text { trend update khususnya di } \\
\text { industri kuliner yang fast moving } \\
\text { guna membangun mental pemilik } \\
\text { (W1, O1, O2) } \\
\text { 2. Menyediakan SDM tambahan/ } \\
\text { meningkatkan komitmen SDM } \\
\text { yang telah ada untuk konsisten } \\
\text { dengan jam kerja di angkringan } \\
\text { karena tuntutan gaya hidup } \\
\text { remaja (W2, O1) }\end{array}$ \\
\hline $\begin{array}{l}\text { Threats } \\
\text { 1. Banyak pesaing } \\
\text { langsung (A.15) } \\
\text { 2. Pesaing benchmark } \\
\text { ke angkringan } \\
\text { (A.16-A.17) }\end{array}$ & $\begin{array}{l}\text { Strategi ST } \\
\text { 1. Menjaga } \\
\text { fleksibilitas, } \\
\text { sikap adaptif } \\
\text { dalam } \\
\text { mengatasi } \\
\text { pesaing } \\
\text { langsung. (S1, } \\
\text { T1) } \\
\text { Menjaga } \\
\text { fleksibilitas dan } \\
\text { sikap adaptif } \\
\text { dalam inovasi } \\
\text { secara kontinu } \\
\text { yang secara } \\
\text { perlahan } \\
\text { menghambat } \\
\text { laju inovasi } \\
\text { pesaing yang } \\
\text { datang untuk } \\
\text { benchmark (S1, } \\
\text { T2) }\end{array}$ & $\begin{array}{l}\text { Strategi WT } \\
\text { 1. Mengikuti seminar } \\
\text { pengembangan diri guna lebih } \\
\text { kuat secara mental menghadapi } \\
\text { kompetitor. (W1, T1) } \\
\text { 2. Menyiapkan SOP yang jelas agar } \\
\text { kompetitor tidak memanfaatkan } \\
\text { ketidakkonsistenan jam buka } \\
\text { angkringan untuk merebut } \\
\text { konsumen (W2, T2) }\end{array}$ \\
\hline
\end{tabular}




\section{Analisis SWOT Angkringan Ngudi Raos}

Analisis SWOT Angkringan Ngudi Raos dilakukan dalam tiga tahapan berikut:

1. Menganalisis lingkungan internal dan eksternal dari Objek (tahapan satu dan dua).

Dalam penelitian ini, analisis lingkungan internal maupun eksternal dilakukan melalui open questions dalam wawancara. Temuan dari hasil wawancara melalui responden/ informan pertama yakni Marga, adalah sebagai berikut:

Tabel 12

Temuan SWOT Angkringan Ngudi Raos

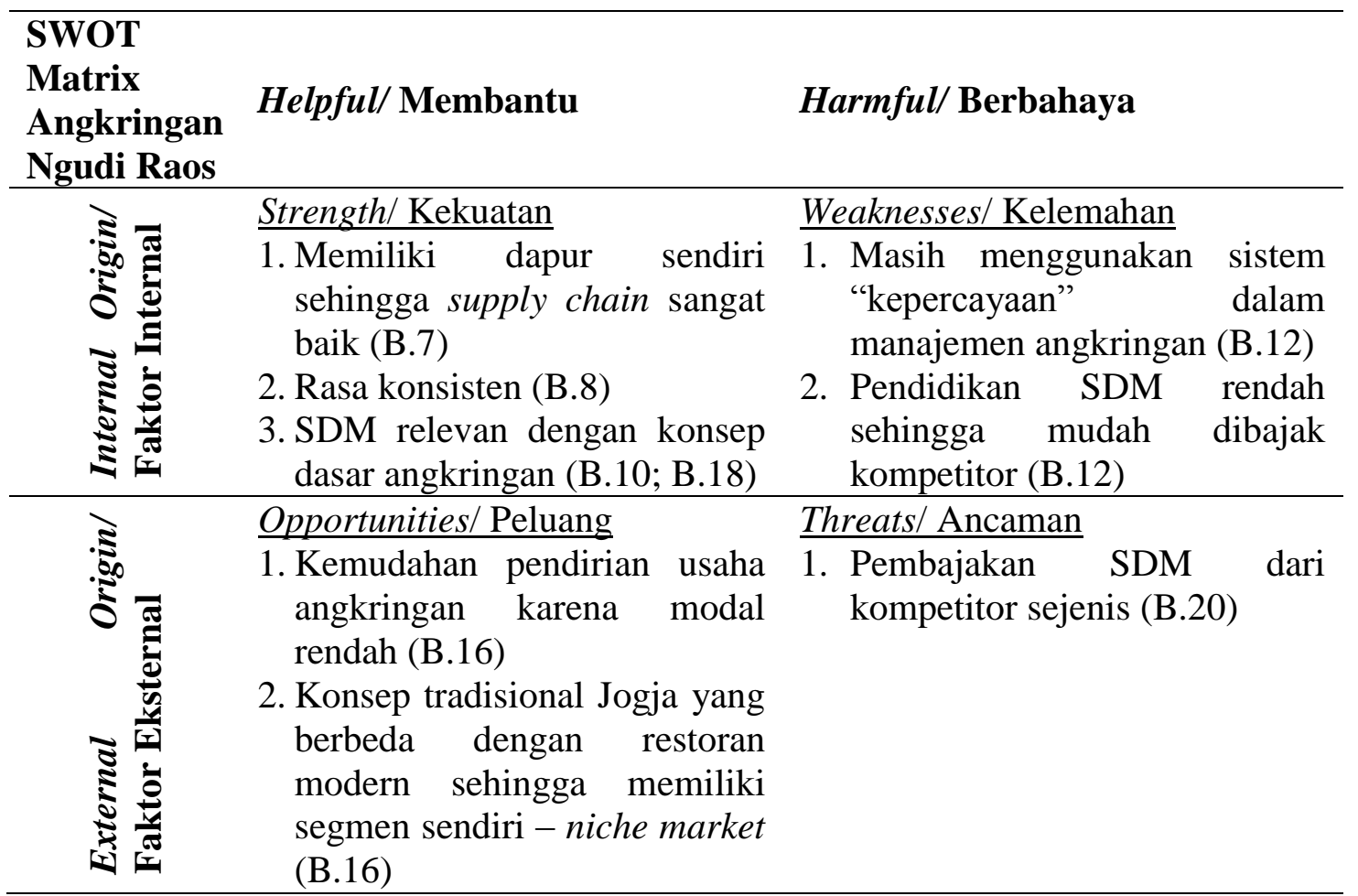

2. Melakukan analisis SWOT dan dokumen dari Objek (tahapan tiga).

Dalam penelitian ini, analisis SWOT berupa strategi-strategi yang dapat diimplementasikan oleh Angkringan Ngudi Raos adalah sebagai berikut:

Tabel 13

Strategi SWOT Angkringan Ngudi Raos

\begin{tabular}{|c|c|c|c|}
\hline Strategi SO & & Strengths & Weaknesses \\
\hline Strategi WO & & 1. Memiliki & 1. Masih menggunakan \\
\hline Strategi ST & & sehingga & "kepercayaan" \\
\hline Strategi WT & & supply & manajemen angkringan (B.12) \\
\hline & & sangat baik (B.7) & 2. Pendidikan \\
\hline $\begin{array}{l}\text { Angkringan } \\
\text { Raos }\end{array}$ & Ngudi & 2. Rasa & $\begin{array}{l}\text { sehingga mudah } \\
\text { kompetitor (B.12) }\end{array}$ \\
\hline & & $\begin{array}{lr}\text { 3. SDM } & \text { relevan } \\
\text { dengan } & \text { konsep } \\
\text { dasar angkringan }\end{array}$ & \\
\hline
\end{tabular}




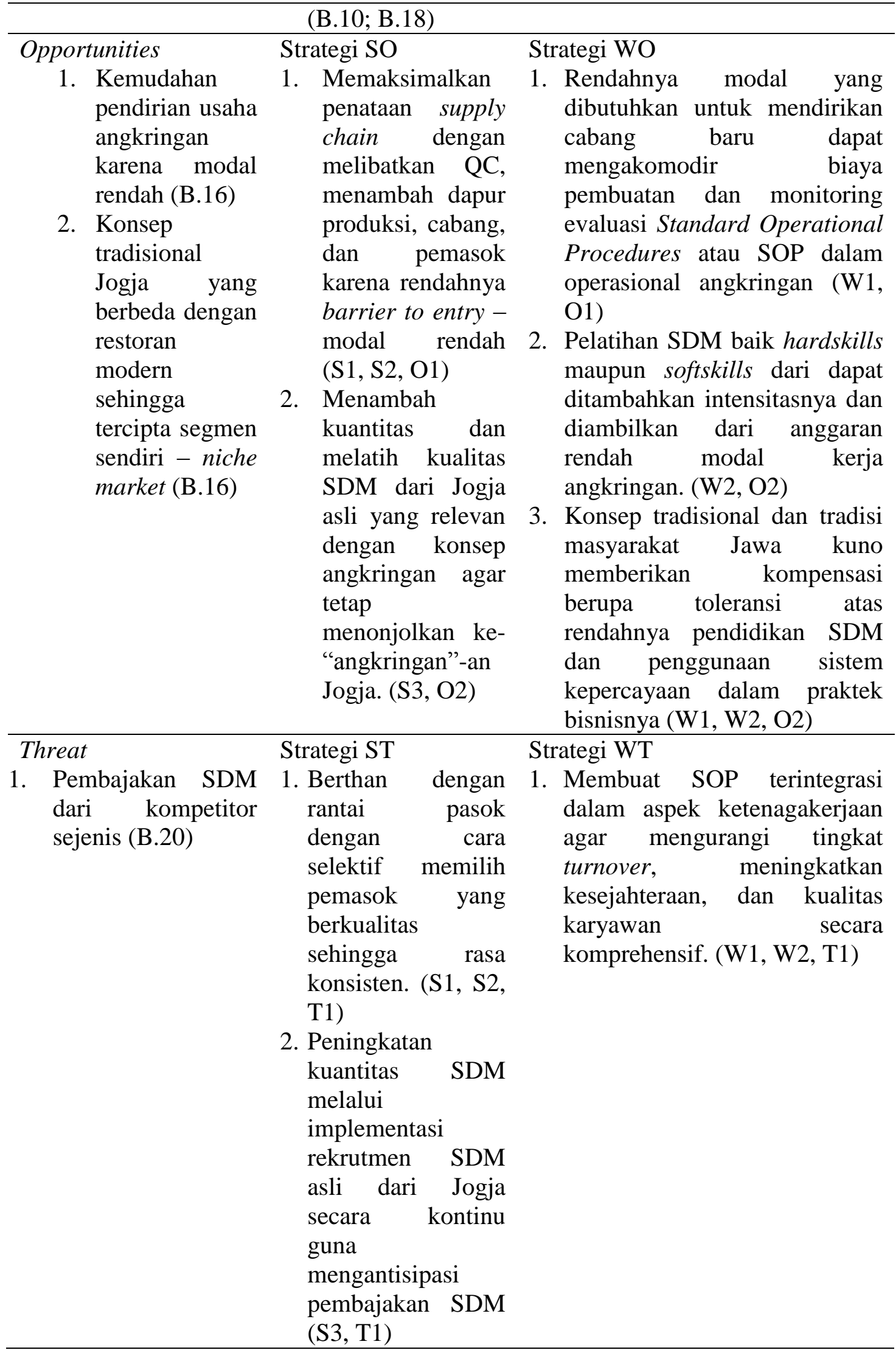




\section{Analisis SWOT Angkringan Ngudi Roso}

Analisis SWOT Angkringan Ngudi Roso dilakukan dalam tiga tahapan berikut:

1. Menganalisis lingkungan internal dan eksternal dari Objek (tahapan satu dan dua).

Dalam penelitian ini, analisis lingkungan internal maupun eksternal dilakukan melalui open questions dalam wawancara. Temuan dari hasil wawancara melalui responden/informan pertama yakni Sugeng dituangkan dalam tabel berikut:

Tabel 14

Temuan SWOT Angkringan Ngudi Roso

\begin{tabular}{|c|c|c|}
\hline $\begin{array}{l}\text { SWOT } \\
\text { Matrix } \\
\text { Angkringan } \\
\text { Ngudi Roso }\end{array}$ & Helpful/ Membantu & Harmful/ Berbahaya \\
\hline 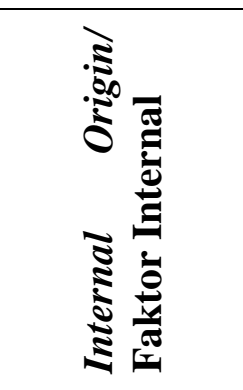 & $\begin{aligned} & \text { Strength/ Kekuatan } \\
& \text { 1. } \text { Memprioritaskan } \\
& \text { pelayanan kepada } \\
& \text { pelanggan (C.14) } \\
& \text { 2. } \text { Memiliki promo } \\
& \text { harian (C.14) } \\
& \text { 3. } \text { Pemilik komunikatif } \\
& \text { (C.15) }\end{aligned}$ & $\begin{array}{l}\text { Weaknesses/ Kelemahan } \\
\text { 1. Lokasi tidak nyaman (C.19) } \\
\text { 2. Rendahnya ketersediaan } \\
\text { produk karena proyeksi } \\
\text { penjualan yang tidak ada } \\
\text { (C.20) }\end{array}$ \\
\hline 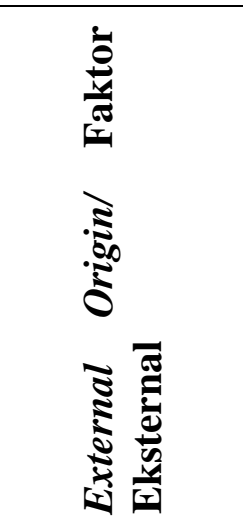 & \begin{tabular}{ll}
\multicolumn{3}{l}{ Opportunities/ Peluang } \\
1. & Preferensi pelanggan \\
& di area Surabaya \\
& kepada makanan berat \\
& (C.21) \\
2. & Perubahan perilaku \\
& pelanggan millenials \\
& yang menuntut adanya \\
& fasilitas modern (C.21)
\end{tabular} & $\begin{array}{l}\text { Threats/ Ancaman } \\
\text { 1. Angkringan dengan konsep } \\
\text { menyimpang jauh dari } \\
\text { aslinya merusak persepsi } \\
\text { publik tentang angkringan, } \\
\text { menjual menu yang berbeda } \\
\text { jauh. (C.17) } \\
\text { 2. } \\
\text { Resto konsep modern dapat } \\
\text { menjadi r alternatif } \\
\text { angkringan rarena } \\
\text { fasilitasnya lebih baik (C.26) }\end{array}$ \\
\hline
\end{tabular}


2. Melakukan analisis SWOT dan dokumen dari Objek (tahapan tiga).

Dalam penelitian ini, analisis SWOT berupa strategi-strategi yang dapat diimplementasikan oleh Angkringan Ngudi Roso adalah sebagai berikut:

Tabel 15

Strategi SWOT Angkringan Ngudi Roso

\begin{tabular}{|c|c|c|}
\hline $\begin{array}{l}\text { Strategi SO } \\
\text { Strategi WO } \\
\text { Strategi ST } \\
\text { Strategi WT }\end{array}$ & $\begin{array}{l}\text { rengths } \\
\text { 1. Memprioritaskan } \\
\text { pelayanan kepada } \\
\text { pelanggan (C.14) } \\
\text { 2. Memiliki promo } \\
\text { harian (C.14) } \\
\text { 3. Pemilik komunikatif } \\
\text { (C.15) }\end{array}$ & $\begin{array}{l}\text { leaknesses } \\
\text { 1. Lokasi tidak nyaman } \\
\text { (C.19) } \\
\text { 2. Rendahnya ketersediaan } \\
\text { produk karena proyeksi } \\
\text { penjualan yang tidak ada } \\
\text { (C.20) }\end{array}$ \\
\hline $\begin{aligned} & \text { Opportunities } \\
& \text { 1. } \text { Preferens } \\
& \mathrm{i} \\
& \text { pelangga } \\
& \mathrm{n} \text { di area } \\
& \text { Surabaya } \\
& \text { kepada } \\
& \text { makanan } \\
& \text { berat } \\
& \text { (C.21) } \\
& \text { 2. } \\
& \text { Perubaha } \\
& \mathrm{n} \\
& \text { perilaku } \\
& \text { pelangga } \\
& \mathrm{n} \\
& \text { millenial } \\
& \mathrm{s} \quad \text { yang } \\
& \text { menuntut } \\
& \text { adanya } \\
& \text { fasilitas } \\
& \text { modern } \\
& \text { (C.21) }\end{aligned}$ & $\begin{array}{l}\text { rategi SO } \\
\text { 1. Menambahkan varian } \\
\text { makanan berat dengan } \\
\text { tetap berpegang pada } \\
\text { konsep Jogja, } \\
\text { pelayanan yang baik, } \\
\text { dan disosialisasikan } \\
\text { melalui promo-promo } \\
\text { (S1, S2, O1) } \\
\text { 2. Pelatihan karyawan } \\
\text { agar meningkatkan/ } \\
\text { mempertahankan } \\
\text { kualitas layanan } \\
\text { sehingga kebutuhan } \\
\text { millenials terpenuhi } \\
\text { dan puas (S1, O2) }\end{array}$ & 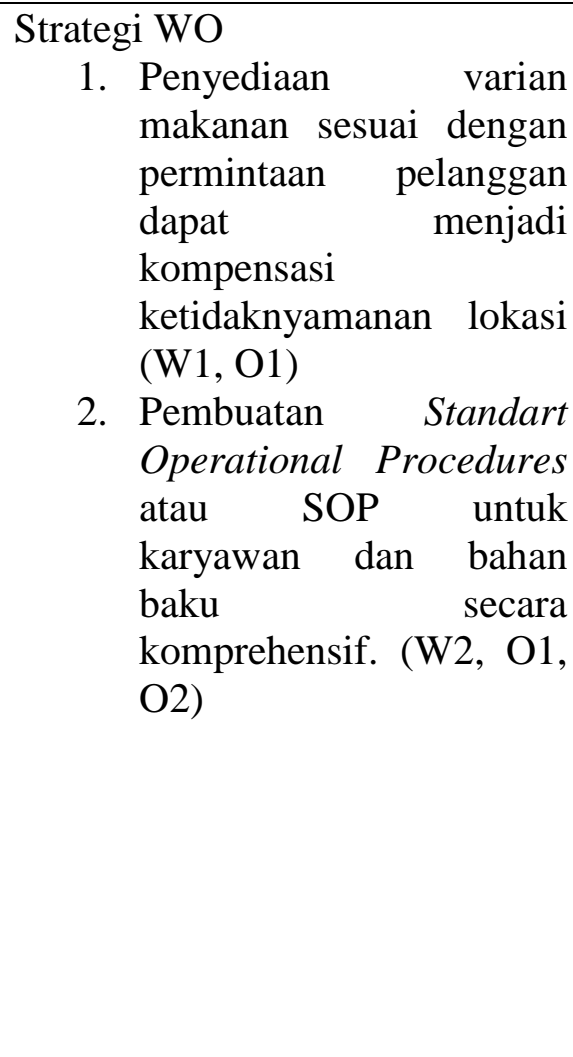 \\
\hline $\begin{array}{l}\text { Threats } \\
\text { 1. Angkrin } \\
\text { gan } \\
\text { dengan } \\
\text { konsep } \\
\text { menyimp } \\
\text { ang jauh } \\
\text { dari } \\
\text { aslinya } \\
\text { merusak } \\
\text { persepsi } \\
\text { publik }\end{array}$ & $\begin{array}{l}\text { trategi ST } \\
\text { 1. Mengedukasi } \\
\text { pelanggan melalui } \\
\text { sosok pemilik yang } \\
\text { komunikatif dan aktif } \\
\text { dalam media sosial } \\
\text { agar cerdas dalam } \\
\text { memilah angkringan } \\
\text { "abal-abal" dan yang } \\
\text { asli. (S2, S3, T1) } \\
\text { 2. Menjaga dan } \\
\text { meningkatkan secara }\end{array}$ & $\begin{array}{l}\text { 1. Mempersiapkan lokasi } \\
\text { alternatif dengan konsep } \\
\text { yang sama (asli Jogja) di } \\
\text { sekitar lokasi angkringan } \\
\text { (W1, T1) } \\
\text { 2. Melakukan } \\
\text { benchmarking atau studi } \\
\text { banding dengan resto } \\
\text { modern terkait SOP atau } \\
\text { sistem proyeksi } \\
\text { penjualan dan }\end{array}$ \\
\hline
\end{tabular}




\begin{tabular}{|c|c|c|c|}
\hline 2. & $\begin{array}{l}\text { tentang } \\
\text { angkring } \\
\text { an, } \\
\text { menjual } \\
\text { menu } \\
\text { yang } \\
\text { berbeda } \\
\text { jauh. } \\
\text { (C.17) } \\
\text { Resto } \\
\text { konsep } \\
\text { modern } \\
\text { dapat } \\
\text { menjadi } \\
\text { alternatif } \\
\text { angkring } \\
\text { an } \\
\text { karena } \\
\text { fasilitasn } \\
\text { ya lebih } \\
\text { baik } \\
\text { (C.26) }\end{array}$ & $\begin{array}{l}\text { kontinu kualitas } \\
\text { layanan agar } \\
\text { pelanggan merasakan } \\
\text { pelayanan yang baik } \\
\text { sama seperti di resto } \\
\text { modern (S1, T2) } \\
\text { 3. Tetap melakukan } \\
\text { pemutakhiran promosi } \\
\text { dan secara kontinu } \\
\text { mengkomunikasikann } \\
\text { ya kepada pelanggan } \\
\text { sehingga mampu } \\
\text { bersaing dengan resto } \\
\text { modern (S2, S3, T2) }\end{array}$ & $\begin{array}{lr}\text { mekanisme } & \text { pelayanan } \\
\text { agar dapat } & \text { membuat } \\
\text { prediksi } & \text { penyediaan } \\
\text { produk yang lebih tepat } \\
\text { (W2, T2) }\end{array}$ \\
\hline
\end{tabular}

\section{Analisis PEST}

Persepsi responden tentang aspek politik, ekonomi, sosial, dan teknologi dalam pernyataan/jawaban responden melalui wawancara yang disimpulkan dari hasil coding transkrip wawancara responden. Analisis PEST juga dapat menjadi strategi bisnis besar bagi Angkringan yang kelak dapat diimplementasikan tidak hanya dalam kegiatan pemasaran melainkan juga pada kegiatan strategis operasional dan pengelolaan SDM.

\section{Analisis PEST Angkringan Teman Lama}

Temuan penelitian dengan objek Angkringan teman lama atas aspek PEST disajikan dalam tabel berikut:

Tabel 16

Temuan PEST Angkringan Teman Lama

\begin{tabular}{|l|ll|}
\hline Aspek PEST & \multicolumn{2}{|c|}{ Temuan } \\
\hline Politik & 1. & Kestabilan secara politik tidak berpengaruh signifikan bagi angkringan \\
& 2. & Regulasi dan de-regulasi tidak berpengaruh signifikan bagi angkringan \\
& 3. & $\begin{array}{l}\text { Hukum/Perda juga tidak membawa dampak bagi proses bisnis } \\
\text { angkringan }\end{array}$ \\
& 2. & Pajak usaha tetap dibayarkan oleh pemilik kepada pemerintah \\
& 3. & Tidak terdapat perjanjian dagang tertentu dengan pihak pemerintah \\
\hline Ekonomi & 1. & Tren ekonomi berpengaruh kepada angkringan \\
& 2. & Stabilitas angkringan tidak dipengaruhi signifikan oleh inflasi, \\
& peningkatan UMR, produk domestik bruto \\
& 3. & Perjanjian dagang dengan pemasok lokal terjadi untuk memenuhi \\
\hline
\end{tabular}




\begin{tabular}{|c|c|}
\hline & $\begin{array}{l}\text { ketersediaan bahan baku } \\
\text { 4. Siklus ekonomi musiman terutama dalam usaha makanan minuman } \\
\text { berdampak pada intensitas inovasi produk yang dijual }\end{array}$ \\
\hline Sosial & $\begin{array}{l}\text { 1. Faktor demografi yang berubah, perilaku konsumen terutama saat } \\
\text { berbelanja dimana generasi millenials menuntut angkringan untuk } \\
\text { lebih fleksibel dalam membuat produk dan melayani mereka } \\
\text { berdampak pada tingkat adaptabilitas angkringan yang meningkat. } \\
\text { 2. Kemampuan pemilik sebagai sosok yang sosialita di kalangannya } \\
\text { menjadi influencer bagi millenials untuk datang ke angkringan }\end{array}$ \\
\hline Teknologi & $\begin{array}{l}\text { 1. Angkringan tidak menutup diri terhadap perkembangan teknologi yang } \\
\text { diproksikan oleh e-commerce via Go-Food atau Go-Send; metode } \\
\text { pembayaran non-tunai; dan penggunaan alat masak modern dalam } \\
\text { proses pengolahan bahan baku. Akan tetapi seluruh teknologi modern } \\
\text { disesuaikan dengan konsep tradisionalitasan angkringan agar tidak } \\
\text { merubah konsep utama angkringan. } \\
\text { 2. Pemanfaatan perangkat lunak Microsoft Excel digunakan pemilik } \\
\text { angkringan untuk melakukan pembukuan/pencatatan arus kas dan } \\
\text { aspek finansial lainnya. }\end{array}$ \\
\hline
\end{tabular}

Analisis PEST pada objek ini dilakukan dalam skala lokal karena objek penelitian terdapat dalam satu kota/area saja (Surabaya) sehingga peneliti berasumsi tidak diperlukan analisis PEST lingkungan operasi pada skala supranasional dan nasional.

\section{Analisis PEST Angkringan Ngudi Raos}

Dalam objek Angkringan Ngudi Raos ini ditemukan persepsi responden tentang aspek politik, ekonomi, sosial, dan teknologi dalam pernyataan/jawaban responden melalui wawancara. Temuannya disajikan dalam tabel berikut:

Tabel 17

Temuan PEST Angkringan Ngudi Raos

\begin{tabular}{|c|c|}
\hline Aspek PEST & Temuan \\
\hline Politik & $\begin{array}{l}\text { 1. Kestabilan secara politik, regulasi dalam bentuk peraturan daerah tidak } \\
\text { berpengaruh signifikan bagi angkringan } \\
\text { 2. Pajak usaha tetap dibayarkan oleh pemilik kepada pemerintah melalui } \\
\text { biaya sewa kepada pemilik lokasi }\end{array}$ \\
\hline Ekonomi & $\begin{array}{l}\text { 1. Tren ekonomi berpengaruh kepada angkringan yang nampak dari } \\
\text { perubahan daya beli tiap pelanggan di area-area tertentu Kota Surabaya } \\
\text { 2. Stabilitas angkringan tidak dipengaruhi signifikan oleh inflasi, } \\
\text { peningkatan UMR, dan PDB. } \\
\text { 3. Limitasi perjanjian dagang dengan beberapa pemasok lokal untuk } \\
\text { memenuhi ketersediaan bahan baku dilakukan agar mengurangi varian } \\
\text { raw material yang berdampak pada penurunan kualitas produk }\end{array}$ \\
\hline Sosial & $\begin{array}{l}\text { 1. Perubahan demografi konsumen dari generasi Y ke millenials berdampak } \\
\text { pada tingkat adaptasi angkringan yang semakin menyesuaikan dan } \\
\text { fleksibel terhadap permintaan millenials } \\
\text { 2. Perilaku konsumen dan belanja yang berubah juga karena perbedaan } \\
\text { generasi memaksa pemilik untuk fleksibel dengan permintaan konsumen }\end{array}$ \\
\hline
\end{tabular}




\begin{tabular}{|l|l|}
\hline Teknologi & 1. Peran teknologi (proksi: e-commerce, kompor listrik, dan metode \\
& pembayaran cashless) tidak signifikan berpengaruh karena model bisnis \\
angkringan tradisional dan implementasi teknologi modern akan kurang & relevan dan malah merubah nilai tradisionalitasan angkringan, bahan \\
baku/ material produk baru, maupun proses produksi/model bisnis yang \\
sebenarnya.
\end{tabular}

Analisis PEST pada Angkringan Ngudi Raos ini dilakukan dalam skala lokal karena objek penelitian terdapat dalam satu kota/area saja (Surabaya) sehingga peneliti berasumsi tidak diperlukan analisis PEST lingkungan operasi pada skala supranasional dan nasional.

\section{Analisis PEST Angkringan Ngudi Roso}

Ditemukan persepsi responden tentang aspek politik, ekonomi, sosial, dan teknologi dalam pernyataan/ jawaban responden melalui wawancara dengan responden Angkringan Ngudi Roso yang disajikan dalam tabel 4.13:

\section{Tabel 18}

Temuan PEST Angkringan Ngudi Roso

\begin{tabular}{|c|c|}
\hline Aspek PEST & Temuan \\
\hline Politik & $\begin{array}{l}\text { 1. Perda UMKM tidak berpengaruh signifikan (tidak berdampak bagi } \\
\text { proses bisnis angkringan) } \\
\text { 2. Pemilik membayar pajak usaha hanya kepada pejabat yang memiliki } \\
\text { izin resmi dari RT setempat (bukan pungutan liar) } \\
\text { 3. Tidak terdapat perjanjian dagang tertentu dengan pihak pemerintah }\end{array}$ \\
\hline Ekonomi & $\begin{array}{l}\text { 1. Tren di sektor ekonomi berpengaruh kepada angkringan } \\
\text { 2. Stabilitas proses bisnis angkringan tidak dipengaruhi signifikan oleh } \\
\text { inflasi, peningkatan UMR, dan PDB } \\
\text { 3. Tidak ada perjanjian dagang dengan pemasok lokal karena pemilik } \\
\text { langsung datang ke pemasok tangan pertama (pemotongan ayam) } \\
\text { 4. Siklus ekonomi musiman terutama dalam usaha makanan minuman } \\
\text { berdampak pada intensitas inovasi produk yang dijual }\end{array}$ \\
\hline Sosial & $\begin{array}{l}\text { 1. Perubahan demografi pelanggan nampak signifikan berpengaruh } \\
\text { karena mayoritas pengunjung adalah generasi millenials yang } \\
\text { memiliki preferensi sosial yang unik dan tidak loyal. } \\
\text { 2. Perilaku belanja millenials memberi pengaruh sosial dan upaya } \\
\text { promosi, inovasi produk varian tambahan dilakukan pemilik untuk } \\
\text { itu. }\end{array}$ \\
\hline Teknologi & $\begin{array}{l}\text { 1. Pemilik tertutup atas kemajuan teknologi terutama di sektor } \\
\text { pembayaran cashless dimana pemilik merasa merepotkan jika } \\
\text { menggunakan mesin transaksi non-tunai. } \\
\text { 2. Proses produksi masih konvensional, belum ada pemutakhiran alat } \\
\text { produksi dan model usaha. }\end{array}$ \\
\hline
\end{tabular}


3. Tidak menggunakan perangkat lunak/ keras untuk pembukuan (pencatatan keuangan konvensional)

Analisis PEST pada Angkringan Ngudi Roso ini dilakukan dalam skala lokal karena objek penelitian terdapat dalam satu kota/area saja (Surabaya) sehingga peneliti berasumsi tidak diperlukan analisis PEST lingkungan operasi pada skala supranasional dan nasional.

\section{Alternatif Strategi Angkringan}

Dari analisis strategi PEST dan SWOT, dapat dirumuskan pula alternatif strategi untuk angkringan untuk meningkatkan pertumbuhan secara intensif ketiga objek angkringan dan dapat pula diimplementasikan oleh angkringan ataupun bentuk usaha makanan minuman tradisional lainnya yang serupa. Strategi pertumbuhan intensif ini terdiri atas beberapa alternatif langkah yang dapat dilakukan angkringan diantaranya (1) Angkringan dapat mempenetrasi pasar dengan cara berfokus pada menjual produk yang telah terjual pada seluruh angkringan seperti wedang uwuh khas angkringan tradisional Jogja. Adapun tujuan mempenetrasi pasar ini adalah untuk mempertahankan bahkan meningkatkan pangsa pasar produk tradisional angkringan. Saat menjual produk yang sudah laku terjual ini, angkringan dapat mengkombinasikan harga kompetitif, iklan, dan promosi penjualan atas produk tersebut. Strategi penetrasi ini juga bertujuan meningkatkan loyalitas pelanggan yang telah ada karena produk yang sudah settled dan diketahui pelanggan akan lebih mudah menjualnya serta lebih murah daripada harus membuat dan berinovasi dengan produk baru; (2) Angkringan dapat mengembangkan pasar dengan cara memperkenalkan produk varian dan inovasi yang telah ada ke dalam pasar yang baru seperti lokasi geografis yang baru dan belum terdapat angkringan disitu/pasar yang belum pernah mencoba wedang $u w u h$, dan sebagainya. Angkringan juga dapat mengembangkan pasar melalui dimensi produk yang baru (kemasan), menggunakan saluran distribusi baru (kombinasi offline angkringan dengan platform GoFood/ Grab-Food), bahkan dapat pula menerapkan kebijakan harga yang baru untuk pasar yang baru (harga lebih mahal untuk area angkringan dengan pelanggan menengah keatas); (3) Angkringan juga dapat mengembangkan produk dengan cara memperkenalkan produk baru ke pasar yang sudah ada. Hal ini memerlukan strategi pengembangan kompetensi baru, litbang yang baru, dan cara pemasaran yang baru pula yang dapat diterapkan ke pasar yang telah sudah ada (menambahkan roti bakar atau jajanan pasar lainnya dengan resiko kehilangan identitas orisinil angkringan itu sendiri); dan (4) pemilik angkringan melakukan diversifikasi di pasar yang baru dengan produk yang baru dimana sangat berisiko karena pemilik mungkin belum mengetahui karateristik pasar yang baru, produk yang baru, dan medan bisnis yang baru (beralih ke depot masakan Indonesia). Ansoff menggambarkan strategi pertumbuhan intensifnya dalam bentuk matrix berikut: 


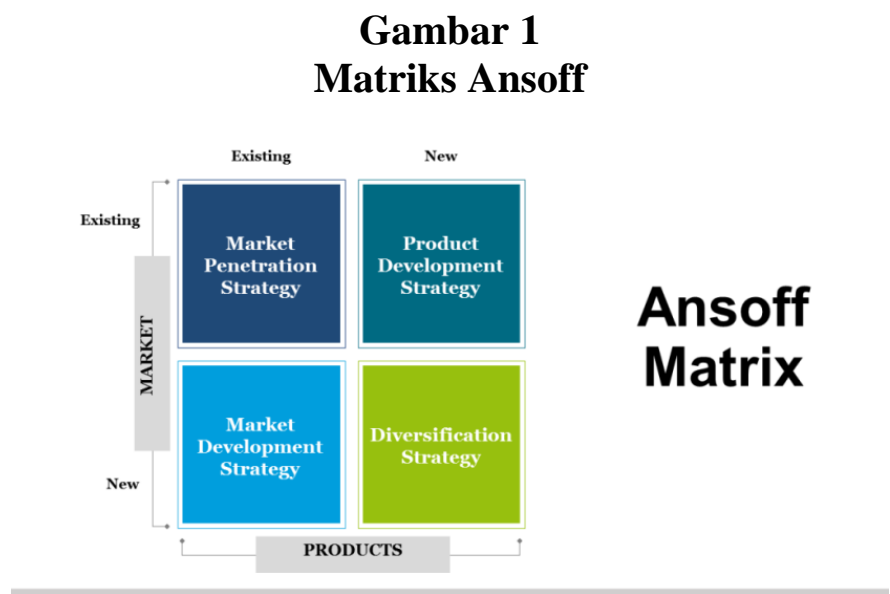

Sumber: (Ansoff 1960) diolah (Malhotra 2018)

Dilihat dari kondisi angkringan penelitian ini, maka pasar yang dimiliki sudah ada dan banyak di daerah penelitian, sedangkan produk yang dimiliki juga sudah ada dan laku terjual namun tidak menutup kemungkinan terdapat produk baru yang beberapa angkringan coba untuk jual dengan resiko kehilangan orisinalitasnya. Di sisi lain, pelanggan yang datang ke angkringan bervariasi/ heterogen sehingga dapat dikatakan segmen pelanggannya dari kalangan bawah hingga atas. Dari hal itu, disarankan penggunaan strategi penetrasi pasar dan pengembangan pasar. Jika ingin mengambil resiko kehilangan orisinalitas angkringan, dapat menggunakan strategi pengembangan produk. (Ansoff 1960 dikutip oleh Hussain dkk 2013)

\section{KESIMPULAN DAN SARAN Kesimpulan}

Berdasarkan temuan penelitian, kajian teori, penelitian sebelumnya, data sekunder lain, dan pembahasan strategi pemasaran, dapat disimpulkan poin penting penelitian ini yakni strategi pemasaran secara garis besar bagi angkringan adalah: (1) perlunya pelatihan secara komprehensif pada UMKM kuliner dalam sektor pengembangan diri pemilik angkringan, (2) pengembangan softskills dan hardskills SDM yang bekerja di dalam angkringan, (3) selalu up-to-date dan adaptif dalam mengikuti perkembangan jaman/ permintaan generasi millenials, (4) berinovasi dan kreatif dalam mengelola angkringan dan terbuka atas perkembangan teknologi, (5) mengelola rantai pasok angkringan dengan baik agar menciptakan kualitas produk yang baik, serta (5) membuat dan mensosialisasikan standart operational procedures atau SOP dalam angkringan untuk memaksimalkan manajemen dan kualitas angkringan secara keseluruhan. Untuk pertumbuhan intensif, angkringan dapat mengimplementasikan strategi (1) penetrasi pasar, (2) pengembangan pasar, ataupun (3) pengembangan produk jika ingin mengambil resiko kehilangan orisinalitas angkringan.

\section{Saran}

Sesuai dengan manfaat penelitian dimana kontribusi penelitian ini diimplikasikan kepada manfaat akademis dan praktis, maka secara akademis penelitian ini berimplikasi pada penelitian selanjutnya yang dapat dilakukan pada objek berbeda atau penelitian lanjutan yang lebih mendalam dan komprehensif menggunakan metode opsi strategi pemasaran lain; sedangkan secara praktis penelitian ini berimplikasi pada implementasi saran dan masukan peneliti pada pembahasan strategi pemasaran yang dapat diselaraskan pada roadmap dan 
tujuan utama angkringan. Secara praktis juga, penelitian ini dapat berimplikasi pada penambahan insight bagi masyarakat atau awam dalam bisnis makanan dan minuman khususnya angkringan berikut strategi pemasaran yang dapat diterapkan di sektor industri kuliner dengan format bisnis selain angkringan.

\section{DAFTAR PUSTAKA}

Aaker, David. 2008. Strategic Market Management

Aghazadeh, H. 2016. Business, Market, and Competitive Analysis (BMCA) Tools and Techniques, Chapter 5 in Principles of Marketology, Vol 1, Palgrave Macmillan, New York, pp. 187-247.

Aini, A. N. 2013. Angkringan: arena demokrasi masyarakat perkotaan dengan simbolisme kejawaan (studi kasus: tiga angkringan di Jakarta). Skripsi Universitas Negeri Jakarta - tidak dipublikasikan.

Baker, M. 2008. The Strategic Marketing Plan Audit. ISBN 1-902433-99-8.

Creswell, J. W. 2009. Research design: Qualitative, quantitative, and mixed methods approaches. London, UK: SAGE Publisher.

David, F. R. 1997. Strategic Management. 1997.

Farris, P., Bendle, N., Pfeifer, P. and Reibstein, D. 2015. Marketing Metrics: The Manager's Guide to Measuring Marketing Performance. FT Press, Ch. 1.

Fine, L. H. 2010. The SWOT Analysis: Using your Strength to Overcome Weaknesses, Using Opportunities to Overcome Threats, Kickit LLC, 2010

Fleitcher, C. and Bensoussan, B. 2002. Strategic and Competitive Analysis: Methods and Techniques for Analyzing Business Competition, Prentice Hall, NJ Prentice Hall.

Frates, J. and Sharp, S. 2005. Using Business Intelligence to Discover New Market Opportunities, Journal of Competitive Intelligence and Management, Vol. 3, No. 1, pp. 16-28.

Gupta, A. 2013. Environment \& PEST analysis: an approach to the external business environment. International Journal of Modern Social Sciences, 2(1), 34-43.

Hanum, M. 2007. Kiat menekuni bisnis catering, warung tenda, angkringan. Absolut: Yogyakarta.

Homburg, C; Sabine K, Harley K. 2009. Marketing Management: A Contemporary Perspective (1st ed.), London.

Humphrey, A. 2005. SWOT analysis for management consulting. SRI alumni Newsletter, 1, 7-8.

Hussain, S., Khattak, J., Rizwan, A., \& Latif, M. A. 2013. ANSOFF matrix, environment, and growth-an interactive triangle. Management and Administrative Sciences Review, 2(2), 196-206.

Indrawati, K. P. (2012). Pembentukan ruang kolektif oleh masyarakat (studi kasus: angkringan Tugu Yogyakarta). Skripsi Universitas Indonesia - tidak dipublikasikan.

Irjayanti, M., \& Azis, A. M. 2012. Barrier factors and potential solutions for Indonesian SMEs. Procedia Economics and Finance, 4, 3-12.

Kerzner, H. 2002. Strategic Planning for Project Management Using a Project Management Using a Project Management Maturity Model, Wiley, p. 6-8.

Malhotra, A. 2018. Complete Guide to Ansoff Matrix Model \& Business Growth Strategies. https://www.slideteam.net/blog/ansoff-matrix-model-business-growth-strategiestemplates-included/

Piercy, N. 2009. Market-Led Strategic Change, Butterworth-Heinemann, 2009 
Rozack, A. 2017. Menikmati Angkringan Tengah Kota Surabaya. Retrieved April 9, 2017, from Lifestyle Surabaya: https://www.jawapos.com/radarsurabaya/read/2017/10/17/20398/menikmatiangkringan-tengah-kota-surabaya

Sammut-Bonnici, T. and Galea, F. 2015. "PEST Analysis" in Wiley Encyclopedia of Management, John Wiley, p. 1.

Smith, J. A., Flowers, P., \& Larkin, M. 2009. Interpretative Phenomenological Analysis: Theory, method and research. Washington: Sage.

Sugiyono. 2014. Memahami Penelitian Kualitatif. Bandung: Alfabeta.

Tjiptono, F. 1997. Strategi Pemasaran ( $2^{\text {nd }}$ ed). Yogyakarta: ANDI Publisher.

West, D., Ford, J. and Ibrahim, E. 2010. Strategic Marketing: Creating Competitive Advantage, Oxford, Oxford University Press, p. 22.

http://www.franchise-expo.co.id/Press/Tips/5-Peluang-Usaha-Kuliner-Yang-Mudah-UntukDi-Jalankan/

https://lifestyle.kompas.com/read/2011/12/26/14534516/tren.dan.tantangan.bisnis.kuliner Vliet, V (2015). 3C model by Kenichi Ohmae. toolshero.com. https://www.jawapos.com/radarsurabaya/read/2017/10/17/20398/menikmati-angkringantengah-kota-surabaya 


\section{LAMPIRAN}

\section{PANDUAN WA WANCARA}

Wawancara dipilih menjadi salah satu teknik pengambilan data karena menurut Esterberg (2002) sebagaimana dikutip oleh Sugiyono (2014), wawancara merupakan jiwa atau hati penelitian sosial. Jurnal dalam ilmu sosial ditemukan semua didasarkan pada wawancara baik penelitian standar maupun mendalam. Data yang didapat dari wawancara seringkali bias. Menurut Sugiyono (2014), bias adalah penyimpangan dari yang seharusnya sehingga dapat dinyatakan bahwa data itu subjektif dan tidak akurat. Untuk mengurangi tingkat bias data, ada tujuh langkah wawancara menurut Lincoln \& Guba (1984) sebagaimana dikutip oleh Sugiyono (2014) yaitu:

5. Menetapkan kepada siapa wawancara ditujukan

6. Menyiapkan pokok masalah yang menjadi bahan pembicaraan

7. Mengawali alur wawancara

Berikut contoh pertanyaan yang dapat diajukan dalam penelitian ini (akan dikembangkan lebih detail lagi dalam penelitian):

Analisis PEST:

- Politik

Seberapa berpengaruh isu politik dan regulasi pemkot dalam bisnis angkringan Anda?

- Ekonomi

Adakah pengaruh pergeseran uang tunai ke non-tunai/elektronik seperti TapCash/E-money dalam bisnis angkringan Anda?

- Sosial

Bagaimana Anda menyiasati pasar di kota besar seperti Surabaya ini yang notabene sangat beragam kelas sosialnya?

- Teknologi

Apakah Anda sudah/tertarik/tidak suka dengan pemanfaatan teknologi dalam angkringan? Entah menggunakan media promosi digital, alat pembuatan produk angkringan yang mutakhir, dsb.

Analisis SWOT:

- $\quad$ Strength

Dalam benak Anda, angkringan ini memiliki kekuatan apa yang membuatnya bertahan hingga saat ini?

- Weakness

Apa sisi kelemahan dari angkringan Anda sehingga memungkinkan pesaing Anda merebut konsumen yang semula ke angkringan ini?

- Opportunity

Adakah peluang ke depannya dalam bisnis angkringan untuk menghadapi semakin maraknya bisnis kuliner dengan platform yang beragam (café, resto keluarga, dsb)? Memungkinkankah itu diraih?

- $\quad$ Threat

Menurut Anda, apa saja yang mengancam bisnis angkringan? Mana yang paling berbahaya? Pesaing langsung/pesaing yang menyediakan produk komplementer/substitusi? Atau bahkan yang bukan berjualan kuliner sekalipun (seperti toko online/kurir makanan online)?

4. Melangsungkan alur wawancara.

5. Mengkonfirmasi ikhtisar hasil wawancara dan mengakhirinya.

6. Menuliskan hasil wawancara ke dalam catatan lapangan. 